\title{
In-situ electrochemical modification of pre-intercalated vanadium bronze cathodes for aqueous zinc-ion batteries
}

\author{
Jianwei $\mathrm{Li}^{1,2 \dagger}{ }^{2}$, Ningyun Hong ${ }^{2 \dagger}$, Ningjing Luo ${ }^{1}$, Haobo Dong ${ }^{4}$, Liqun Kang ${ }^{5}$, Zhengjun Peng ${ }^{2}$, \\ Guofeng $\mathrm{Jia}^{2}$, Guoliang Chai ${ }^{{ }^{*}}$, Min Wang ${ }^{2 *}$ and Guanjie $\mathrm{He}^{3,4,5^{*}}$
}

\begin{abstract}
Vanadium bronzes have been well-demonstrated as promising cathode materials for aqueous zinc-ion batteries. However, conventional single-ion pre-intercalated $\mathrm{V}_{2} \mathrm{O}_{5}$ nearly reached its energy/power ceiling due to the nature of micro/electronic structures and unfavourable phase transition during $\mathrm{Zn}^{2+}$ storage processes. Here, a simple and universal in-situ anodic oxidation method of quasi-layered $\mathrm{CaV}_{4} \mathrm{O}_{9}$ in a tailored electrolyte was developed to introduce dual ions $\left(\mathrm{Ca}^{2+}\right.$ and $\left.\mathrm{Zn}^{2+}\right)$ into bilayer $\delta$ - $\mathrm{V}_{2} \mathrm{O}_{5}$ frameworks forming crystallographic ultra-thin vanadium bronzes, $\mathrm{Ca}_{0.12} \mathrm{Zn}_{0.12} \mathrm{~V}_{2} \mathrm{O}_{5} \cdot n \mathrm{H}_{2} \mathrm{O}$. The materials deliver transcendental maximum energy and power densities of $366 \mathrm{~W} \mathrm{~h} \mathrm{~kg}^{-1}$ $\left(478 \mathrm{~mA} \mathrm{~h} \mathrm{~g}\right.$ @ $\left.0.2 \mathrm{~A} \mathrm{~g}^{-1}\right)$ and $6627 \mathrm{~W} \mathrm{~kg}^{-1}\left(245 \mathrm{~mA} \mathrm{~h} \mathrm{~g} \mathrm{~g}^{-1} @\right.$ $10 \mathrm{~A} \mathrm{~g}^{-1}$ ), respectively, and the long cycling stability with a

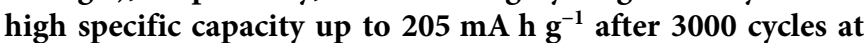
$10 \mathrm{~A} \mathrm{~g}^{-1}$. The synergistic contributions of dual ions and $\mathrm{Ca}^{2+}$ electrolyte additives on battery performances were systematically investigated by multiple in-/ex-situ characterisations to reveal reversible structural/chemical evolutions and enhanced electrochemical kinetics, highlighting the significance of electrolyte-governed conversion reaction process. Through the computational approach, reinforced "pillar" effects, charge screening effects and regulated electronic structures derived from pre-intercalated dual ions were elucidated for contributing to boosted charge storage properties.
\end{abstract}

Keywords: in-situ electrochemical conversion, dual-ion preintercalated $\mathrm{V}_{2} \mathrm{O}_{5}$, electrolyte-controlled conversion, zinc ion batteries

\section{INTRODUCTION}

The burgeoning energy market is hastening the development of electrochemical energy in terms of safety, eco-friendliness and economic sustainability [1]. Although Li-ion batteries prevail in last decades with the significant revolution, flammable and toxic organic electrolytes, the dendrite formation and the degradation of electrode/electrolyte with the oxygen release trigger serious safety issues for their grid-scale application [2]. Meanwhile, limited lithium resource inhibits the realisation of cost-effective application, and intrinsically low ionic conductivity of nonaqueous electrolyte (ca. $1-10 \mathrm{mS} \mathrm{cm}^{-1} v s .>1 \mathrm{~S} \mathrm{~cm}^{-1}$ in aqueous system) restricts their specific use for high-power demands [3]. By comparison, aqueous zinc-ion batteries (AZIBs) adopt neutral/mildly acidic (pH: 3.6-6) electrolytes and metallic zinc anode, which can effectively tackle the safety and economic drawbacks as mentioned above owing to numerous merits such as high abundance, facile fabrication, environmental benignity and electrochemical stability $(-0.76 \mathrm{~V}$ vs. standard hydrogen electrode) of the zinc in aqueous electrolytes [4-7]. In addition, high theoretical capacities $\left(820 \mathrm{~mA} \mathrm{~h} \mathrm{~g}^{-1} / 5851 \mathrm{~mA} \mathrm{~h} \mathrm{~cm}^{-3}\right)$ of the zinc anode endow overwhelming electrochemical storage capability compared with other developed alkali metal-ion $\left(\mathrm{Na}^{+}\right.$and $\left.\mathrm{K}^{+}\right)$or multivalent-ion batteries such as $\mathrm{Mg}^{2+}$ $\left(3833 \mathrm{~mA} \mathrm{~h} \mathrm{~cm}^{-3}\right)$ and $\mathrm{Ca}^{2+}\left(2073 \mathrm{~mA} \mathrm{~h} \mathrm{~cm}^{-3}\right)$ [8,9]. However, AZIBs are still suffering from underdeveloped cathode materials because of sluggish kinetics related with the strong electrostatic interaction between divalent species (i.e., $\mathrm{Zn}^{2+}$ and hydrated $\mathrm{Zn}^{2+}$ ) and the host framework [10]. Generally, vanadium-based cathode materials (vanadium bronzes in particular) possess better capacity and rate capability compared with manganeseand Prussian blue-based cathodes in AZIBs [11-13], and hence, are more adequate for high power use [14]. However, structural collapse/dissolution, irreversible phase transformation and poor electronic conductivity of cathode materials are concretely responsible for unsatisfactory cycling stability and relatively low specific capacity $\left(<430 \mathrm{~mA} \mathrm{~h} \mathrm{~g}{ }^{-1}\right)$ of $\mathrm{M}_{x} \mathrm{~V}_{2} \mathrm{O}_{5} \cdot n \mathrm{H}_{2} \mathrm{O}$ cathodes $(\mathrm{M}$ : $\mathrm{Ca}^{2+}, \mathrm{Zn}^{2+}, \mathrm{Ni}^{2+}$ and $\mathrm{Cu}^{2+}$ etc.) [15-18], which result in much less charge storage capability than the theoretical capacity of $585 \mathrm{~mA} \mathrm{~h} \mathrm{~g}^{-1}$ for $\mathrm{V}_{2} \mathrm{O}_{5}$. Compared with wet chemistry synthetic methods, in-situ anodic oxidation of active materials is more controllable to deliver stable phases for batteries. Therefore, numerous studies have successfully proved that typical types of vanadium $\left(\mathrm{V}^{3+}\right.$ or $\left.\mathrm{V}^{4+}\right)$ oxides can be oxidised to higher-valence

\footnotetext{
${ }^{1}$ State Key Laboratory of Structural Chemistry, Fujian Institute of Research on the Structure of Matter, Chinese Academy of Sciences (CAS), Fuzhou 350002, China

${ }^{2}$ Key Laboratory of Comprehensive and Highly Efficient Utilization of Salt Lake Resources, Qinghai Institute of Salt Lakes, Chinese Academy of Sciences (CAS), Xining 810008, China

${ }^{3}$ School of Chemistry, University of Lincoln, Joseph Banks Laboratories, Green Lane, Lincoln, LN6 7DL, United Kingdom

${ }^{4}$ Department of Chemistry, University College London, 20 Gordon Street, London WC1H 0AJ, United Kingdom

${ }^{5}$ Department of Chemical Engineering, University College London, London WC1E 7JE, United Kingdom

$\dagger$ These authors contributed equally to this work.

* Corresponding authors (emails: g.chai@fjirsm.ac.cn (Chai G); wangmin@isl.ac.cn (Wang M); g.he@ucl.ac.uk (He G))
} 
vanadium compounds by reacting with $\mathrm{H}_{2} \mathrm{O}$ under the $1^{\text {st }}$ charge treatment in pure zinc triflate electrolyte [19-23]. However, inadequate structural features of initial materials such as large particle size and tremendous crystallographic contrast to converted phases could result in insufficient transformation of cathodes and the formation of unfavourable defects, which can deteriorate electrochemical behaviours such as energy efficiency and cycling stability [20,21]. Additionally, only considering the initial mass of electrode materials but not converted materials (e.g., the conversion of $\mathrm{V}_{2} \mathrm{O}_{3}$ or $\mathrm{VO}_{2}$ to $\mathrm{V}_{2} \mathrm{O}_{5}$ ) can cause inaccurate capacity evaluations for ultimate battery performance, leading to overestimated specific capacity far above the theoretical value $[20,21]$. Therefore, it is expected that there are less energy used for side reactions during the electrochemical conversion process and reasonable assessments can be conducted for converted materials in AZIBs.

Inspired by the previous investigation on vanadium-based cathodes, we developed crystallographic quasi-layer ultra-thin ( $\sim 2 \mathrm{~nm}$ in thickness) $\mathrm{CaV}_{4} \mathrm{O}_{9}$ nanoflakes as the initial structure of cathode materials for AZIBs. Through the in-situ electrochemical conversion process, innate $\mathrm{VO}_{5}\left(\mathrm{~V}^{4+}\right)$ square pyramids coordinated $\mathrm{Ca}^{2+}$ within $\mathrm{V}_{4} \mathrm{O}_{9}$ slabs were oxidised to $\mathrm{VO}_{6}$ $\left(\mathrm{V}^{4+/ 5+}\right)$ along with the adsorption of $\mathrm{Zn}^{2+}$ for the charge balance. As the result, $\mathrm{Ca}_{0.10} \mathrm{Zn}_{0.14} \mathrm{~V}_{2} \mathrm{O}_{5} \cdot n \mathrm{H}_{2} \mathrm{O}$ materials were effectively generated upon the first charge treatment (anodic oxidisation) in a tailored electrolyte $\left(\mathrm{Zn}\left(\mathrm{CF}_{3} \mathrm{SO}_{3}\right)_{2}\right.$ aqueous solution with $\mathrm{Ca}\left(\mathrm{CF}_{3} \mathrm{SO}_{3}\right)_{2}$ as the additive) without the observation of other side reactions or impurities, which was systematically verified by ex-situ X-ray diffraction (XRD), ex-situ X-ray photoelectron spectroscopy (XPS), ex-situ Raman and ex-situ scanning transmission electron microscopy-energy dispersive X-ray spectroscopy (STEM-EDS) to confirm their vanadium bronze structure and chemical states. Moreover, the density functional theory (DFT) calculation and several characterisations verified that the dual ions $\left(\mathrm{Ca}^{2+}\right.$ and $\left.\mathrm{Zn}^{2+}\right)$ can jointly improve the structural stability by enhanced binding force within the bilayers of $\mathrm{V}_{2} \mathrm{O}_{5}$ ("pillar" effect), and offer abundant coordination of the structural water to acquire the reinforced screening effect endowing superior charge diffusion kinetics [23]. Meanwhile, the optimised electronic structure in the as-prepared cathodes reveals that higher electronic conductivity was achieved compared with single ion $\left(\mathrm{Ca}^{2+}\right.$ or $\left.\mathrm{Zn}^{2+}\right)$ pre-intercalated $\mathrm{V}_{2} \mathrm{O}_{5}$ framework. Accordingly, the as-prepared materials exhibit a highly reversible specific capacity of $478 \mathrm{~mA} \mathrm{~h} \mathrm{~g}^{-1} @ 0.2 \mathrm{~A} \mathrm{~g}^{-1}$ and outstanding rate capability of $51.3 \%$ capacity retention even after increasing current densities from 0.2 to $10 \mathrm{~A} \mathrm{~g}^{-1}$, which is better than $\mathrm{Ca}^{2+}$ and $\mathrm{Zn}^{2+}$ deficient materials $\left(\mathrm{Ca}_{0.02} \mathrm{Zn}_{0.07} \mathrm{~V}_{2} \mathrm{O}_{5} \cdot n \mathrm{H}_{2} \mathrm{O}\right.$ generated in $\mathrm{Zn}\left(\mathrm{CF}_{3} \mathrm{SO}_{3}\right)_{2}$ electrolyte) and other reported vanadium-based cathodes for AZIBs (Table S1). Therefore, the addition of $\mathrm{Ca}\left(\mathrm{CF}_{3} \mathrm{SO}_{3}\right)_{2}$ in the electrolyte played a crucial role for maintaining high performance not only from adjusting the phase conversion reaction, but from suppressing the cathode dissolution (Le Chatelier's principle) and enhancing the ionic conductivity of the electrolyte. Interestingly, changing triflate salts in aqueous electrolytes is valid for the preparation of other dual-ion $\left(\mathrm{Mg}^{2+}\right.$ and $\left.\mathrm{Ca}^{2+}\right)$ pre-intercalated vanadium bronzes from pristine $\mathrm{CaV}_{4} \mathrm{O}_{9}$ cathodes, suggesting a wide applicability of the approach. Therefore, a new strategy for the materials design is proposed in this work to boost the structural advantages and charge carrier kinetics for vanadium bronze cathode materials, and ultimately pave an avenue for developing superior aqueous batteries.

\section{RESULTS AND DISCUSSION}

Calcium vanadate crystallizes in the tetragonal structure $(P 4 / n)$, which encompasses quasi-two-dimensional (2D) crystal structure consisting of close-packed $\left[\mathrm{V}_{4} \mathrm{O}_{9}\right]_{n}^{2 n-}$ slabs and $\mathrm{Ca}^{2+}$ cations. The vertex-sharing $\mathrm{VO}_{5}\left(\mathrm{~V}^{4+}\right)$ square pyramids in $\mathrm{V}-\mathrm{O}$ chains coordinate with the interlayer $\mathrm{Ca}^{2+}$ generating analogical crystallographic characters compared with $\delta$-phase vanadium bronzes which possess $\mathrm{VO}_{6}\left(3 / 4 \mathrm{~V}^{5+}\right.$ and $\left.1 / 4 \mathrm{~V}^{4+}\right)$ distorted octahedra in $\mathrm{V}_{2} \mathrm{O}_{5}$ bilayer motif [24]. Thus, our hypothetical phase transformation from crystallographic perspective is illustrated in Fig. S1 (Supplementary information). Additionally, the pre-intercalated $\mathrm{Ca}^{2+}$ in $\mathrm{V}_{4} \mathrm{O}_{9}$ layers can be also substituted by other metal/non-metal ions to form quasi-2D compounds with distinctive physicochemical properties which could promisingly broaden the selectivity of cathodes in AZIBs $[25,26]$. Hence, in view of the special crystallographic features of $\mathrm{CaV}_{4} \mathrm{O}_{9}$, we considered employing it as the initial structure for the further modification. The synthesis of $\mathrm{CaV}_{4} \mathrm{O}_{9}$ was achieved by a facile single-step hydrothermal reaction. The XRD pattern of the asprepared $\mathrm{CaV}_{4} \mathrm{O}_{9}$ is shown in Fig. 1a, it can be seen that all diffraction peaks can be indexed to tetragonal $\mathrm{CaV}_{4} \mathrm{O}_{9}$ (ICSD:70$1325)$ in a space group of $P 4 / n$ without any impurity phases, and the (001) peak locates at the Bragg angle of $17.7^{\circ}$ indicating an interlayer space of $0.5 \mathrm{~nm}$ along the $c$-axis. The atomic force microscopy (AFM) measurement clearly offers the thickness of the as-obtained materials, which presents a homogeneous thickness of $\sim 2 \mathrm{~nm}$ as shown in Fig. 1b, c. Similarly, the typical morphology detected by scanning electron microscope (SEM) further confirms their nano-flake structures with a diameter of $\sim 500 \mathrm{~nm}$. It is believed that such morphological features containing few atomic layers can effectively shorten the ion diffusion pathway and deliver a rapid electron transfer. The HRTEM image in Fig. 1e provides the lattice fringe feature with the $d$ space of $1.86 \AA$, in accordance with a diffraction peak of (140) plane from the XRD result. Additionally, from STEM-high-angle annular dark field (HAADF)-EDS mapping analysis, there is a uniform distribution of elemental $\mathrm{Ca}$ and $\mathrm{V}$ in the materials with a ratio of 1:3.9.

\section{Electrochemical evaluations}

To evaluate the electrochemical conversion processes and the battery performance, both coin cells and Swagelok cells were assembled using metallic zinc foils and glass fibres as anodes and separators, respectively. Additionally, it should be noted that three electrolytes, i.e., $3 \mathrm{~mol} \mathrm{~L}^{-1} \mathrm{Zn}\left(\mathrm{CF}_{3} \mathrm{SO}_{3}\right)_{2}$, the mixture of $3 \mathrm{~mol} \mathrm{~L}^{-1} \mathrm{Zn}\left(\mathrm{CF}_{3} \mathrm{SO}_{3}\right)_{2}$ with $0.5 \mathrm{~mol} \mathrm{~L}{ }^{-1} \mathrm{Ca}\left(\mathrm{CF}_{3} \mathrm{SO}_{3}\right)_{2}$ electrolyte additives, and $3 \mathrm{~mol} \mathrm{~L}^{-1} \mathrm{ZnSO}_{4}$, were adopted to investigate different electrochemical/structural evaluation of cathode materials after the initial conversion reaction and battery cycling processes. The first five cyclic voltammetry $(\mathrm{CV})$ curves of the materials in two different electrolytes (pure $\mathrm{Zn}\left(\mathrm{CF}_{3} \mathrm{SO}_{3}\right)_{2}$ and the one with $\mathrm{Ca}^{2+}$ electrolyte additives) were illustrated in Fig. S2 at a scan rate of $0.2 \mathrm{mV} \mathrm{s}^{-1}$ within the operating window of 0.3-1.7 V. Interestingly, the highest anodic oxidation peaks during the first cycle normally referring to the depletion of calcium and the oxidation of vanadyl groups are not at the same potential for these electrodes. A clear shift of the peak from 1.61 to $1.68 \mathrm{~V}\left(v s . \mathrm{Zn} / \mathrm{Zn}^{2+}\right.$ ) is observed in the mixture electrolyte, 

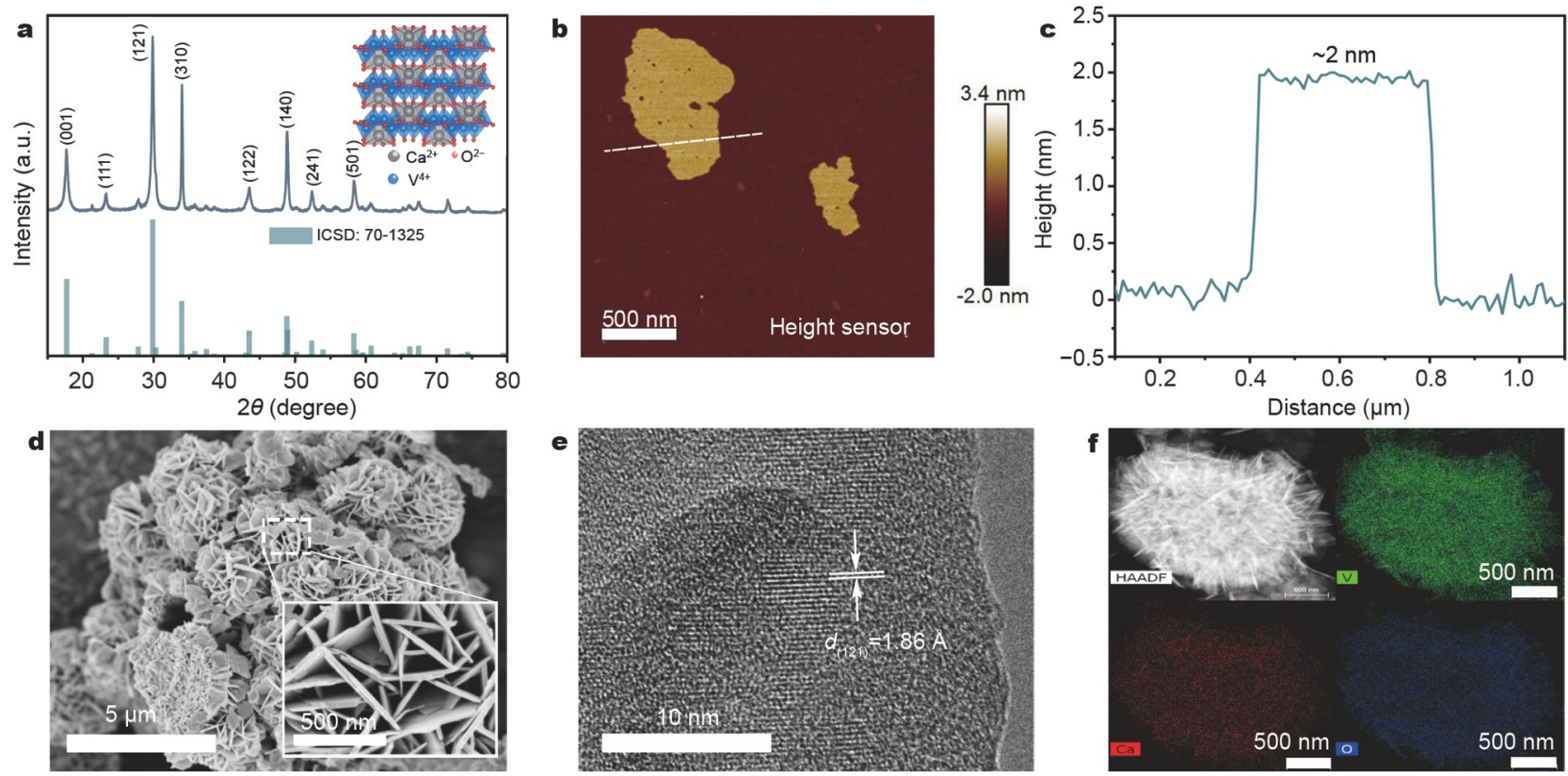

Figure 1 Characterisations of $\mathrm{CaV}_{4} \mathrm{O}_{9}$ : (a) XRD pattern of the as-obtained calcium vanadate and its corresponding standard pattern CaV $\mathrm{O}_{9}$ ( $\mathrm{ICSD}_{\mathrm{C}}$ : 70 1325). Inset in (a): the illustration of its crystal structure; (b, c) AFM image of the as-prepared $\mathrm{CaV}_{4} \mathrm{O}_{9}$ nanoflakes and the thickness of nanoflakes; (d) SEM image of $\mathrm{CaV}_{4} \mathrm{O}_{9}$ materials with the homogeneous nanoflake structure. Inset in (d): cross-section of the nanoflakes from the top view; (e, f) HRTEM, STEM and HAADF-EDS mapping images of $\mathrm{CaV}_{4} \mathrm{O}_{9}$.

which indicates an increased chemical reaction potential required for this process. A hypothesis can be made that introducing $\mathrm{Ca}^{2+}$ species into the electrolyte can suppress the depletion and oxidation processes. However, CV curves in both electrolytes reach a plateaued state during the following few cycles, which depicts a rapid conversion process for $\mathrm{CaV}_{4} \mathrm{O}_{9}$ cathodes. Meanwhile, it is expected that the variation of anodic oxidation process in the first cycle could improve the electrochemical behaviours of the converted active materials in the following cycles. Identically, Fig. 2a clearly exhibits two redox pairs at a scan rate of $1 \mathrm{mV} \mathrm{s}^{-1}$ in both pure $\mathrm{Zn}\left(\mathrm{CF}_{3} \mathrm{SO}_{3}\right)_{2}$ aqueous electrolytes and the one with $\mathrm{Ca}^{2+}$ additives. However, the variation of the integral area and the peak current position imply distinct differences. More specifically, the battery with $\mathrm{Ca}\left(\mathrm{CF}_{3} \mathrm{SO}_{3}\right)_{2}$ as the electrolyte additive possesses smaller potential differences between the two pairs of anodic and cathodic peaks, respectively, along with relatively large specific currents at each potential compared with those in pure $\mathrm{Zn}\left(\mathrm{CF}_{3} \mathrm{SO}_{3}\right)_{2}$ electrolyte, which indicates less polarisation (e.g., better diffusion kinetics) and higher capacity upon fast scan rates.

The further galvanostatic (dis)charge (GCD) profiles of batteries with $\mathrm{Ca}^{2+}$ electrolyte additives showing the zinc (de)intercalation into converted cathode materials are displayed in Fig. S3a and Fig. 2b, of which the first 10 cycles of GCD profiles at the current density of $0.2 \mathrm{~A} \mathrm{~g}^{-1}$ show a fast conversion reaction within almost one anodic oxidation process; the following cycles of GCD profiles almost overlap with each other showing $>99 \%$ Coulombic efficiency. Additionally, even though the applied current densities increased from 0.2 to $10 \mathrm{~A} \mathrm{~g}^{-1}$, GCD profiles of converted cathode materials with $\mathrm{Ca}^{2+}$ electrolyte additives remain similar shapes and a small polarisation, which consists with the observation from the CV results. Moreover, the cyclic stability of the converted cathode at the current density of $0.2 \mathrm{~A} \mathrm{~g}^{-1}$ is carried out in both electrolytes with and without $\mathrm{Ca}^{2+}$ additives, as shown in Fig. S3b. The cycling performances of both electrodes possess the similar outcome for the initial $\sim 30$ cycles with a short activation process at the first few cycles. However, after 160 cycles of GCD measurement, the battery with the pure $\mathrm{Zn}\left(\mathrm{CF}_{3} \mathrm{SO}_{3}\right)_{2}$ electrolyte presents more serious capacity decay ( $40 \%$ against the specific capacity of $449.2 \mathrm{~mA} \mathrm{~h} \mathrm{~g}^{-1}$ for the $1^{\text {st }}$ discharge cycle) compared with the one with $\mathrm{Ca}^{2+}$ electrolyte additives (25\% against specific capacity of $449.3 \mathrm{~mA} \mathrm{~h} \mathrm{~g}^{-1}$ for the $1^{\text {st }}$ discharge cycle). It could be attributed to different structural evaluations upon zinc insertion/extraction processes. Furthermore, the rate capability of different groups were also evaluated by increasing the applied current density from 0.2 to $10 \mathrm{~A} \mathrm{~g}^{-1}$ stepwise. It can be seen that both batteries in different electrolytes present outstanding specific discharge capacity at $0.2 \mathrm{~A} \mathrm{~g}^{-1}$ with the maximum values of 478 and $476 \mathrm{~mA} \mathrm{~h} \mathrm{~g}^{-1}$ for the ones with and without $\mathrm{Ca}^{2+}$ electrolyte additives, respectively. Impressively, even though the current rate increased by fifty-fold times compared with initial cycles, the battery with the mixture electrolyte could still deliver a high capacity of $245 \mathrm{~mA} \mathrm{~h} \mathrm{~g}^{-1}$, which outperforms the one with pure $\mathrm{Zn}\left(\mathrm{CF}_{3} \mathrm{SO}_{3}\right)_{2}$ electrolyte $\left(\sim 178 \mathrm{~mA} \mathrm{~h} \mathrm{~g}{ }^{-1}\right)$. Therefore, an excellent rate capability of $51 \%$ capacity retention (only $37 \%$ for the one in pure $\mathrm{Zn}\left(\mathrm{CF}_{3} \mathrm{SO}_{3}\right)_{2}$ electrolyte) was achieved after the increase of current densities for the battery with $\mathrm{Ca}^{2+}$ electrolyte additives. Meanwhile, the specific capacities are 460, 439, $405,378,335 \mathrm{~mA} \mathrm{~h} \mathrm{~g}^{-1}$ and 444, 404, 346, 307, $205 \mathrm{~mA} \mathrm{~h} \mathrm{~g}^{-1}$ at current densities of $0.5,1,2,3,5 \mathrm{~A} \mathrm{~g}^{-1}$ for batteries with and without $\mathrm{Ca}^{2+}$ additives, respectively. An obvious manifestation can be observed in the rate performance evaluation that both batteries in different electrolytes have varied specific capacity especially under high rates, which is in accordance with fast CV scans. Comparably, long cycling stability at $10 \mathrm{~A} \mathrm{~g}^{-1}$ for both batteries are presented in Fig. $2 \mathrm{~d}$, in which a higher specific 

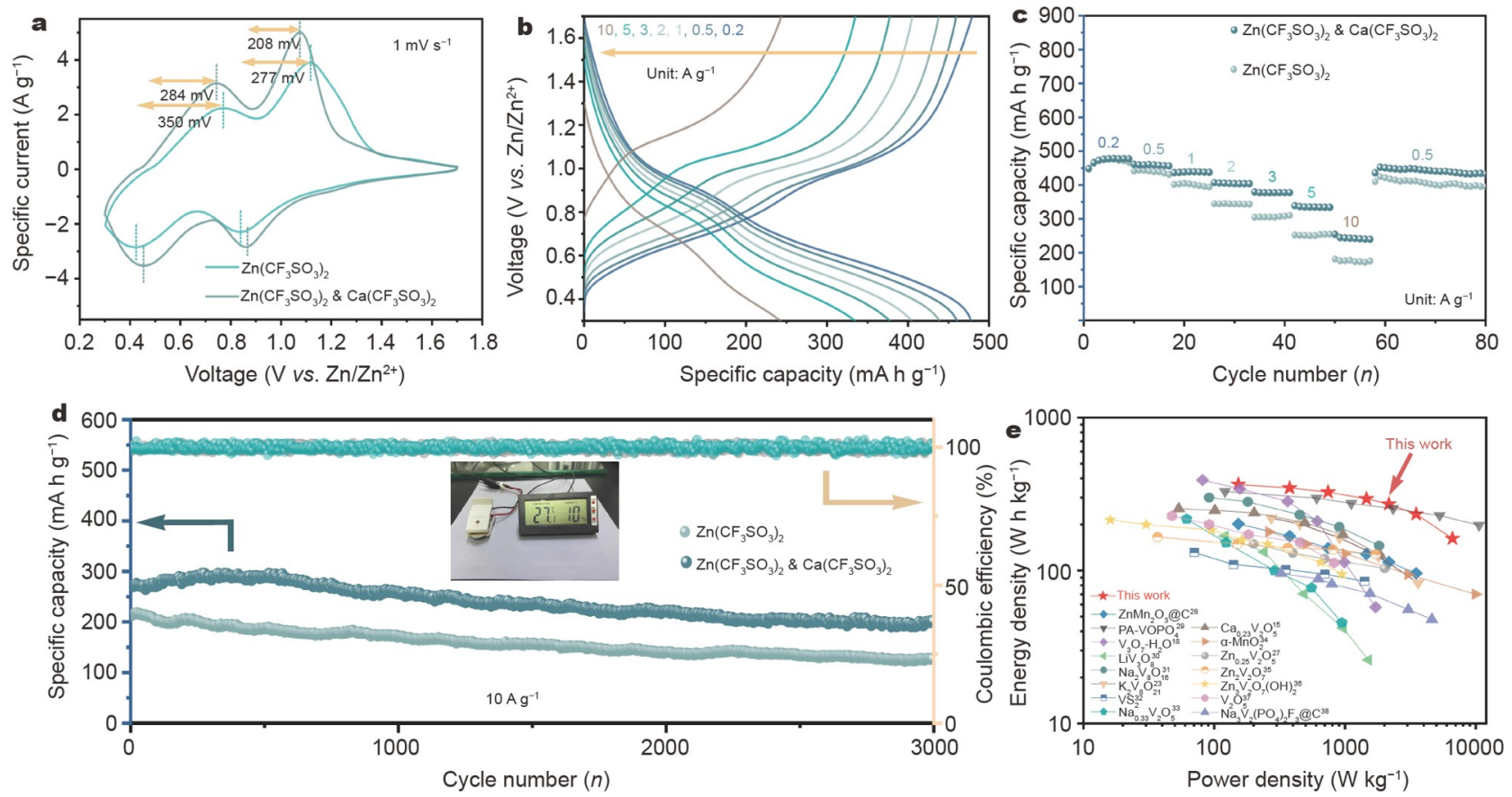

Figure 2 Electrochemical measurements of (a) $\mathrm{CV}$ curves for batteries with pure $\mathrm{Zn}\left(\mathrm{CF}_{3} \mathrm{SO}_{3}\right)_{2}$ and $\mathrm{Ca}^{2+}$ additive-based electrolyte at the scan rate of $1 \mathrm{mV} \mathrm{s}^{-1}$, respectively; (b) GDC profiles for converted $\mathrm{CaV}_{4} \mathrm{O}_{9}$ cathodes with $\mathrm{Ca}^{2+}$ additives under different current densities; (c, d) rate performance and long cycling stability of converted $\mathrm{CaV}_{4} \mathrm{O}_{9} / / \mathrm{Zn}$ batteries in pure and $\mathrm{Ca}^{2+}$ additive-based electrolytes, respectively. Inset (d): digital image of the as-assembled coin cell lightening an electronic device; (e) the Ragone plot of converted cathodes, in comparison with other reported cathode materials for AZIBs.

capacity and less capacity fading (24\%) were achieved with $\mathrm{Ca}^{2+}$ electrolyte additives compared with the one $(40 \%$ capacity attenuation) in pure $\mathrm{Zn}\left(\mathrm{CF}_{3} \mathrm{SO}_{3}\right)_{2}$ electrolytes after 3000 cycles measurement. Therefore, the high reversibility, rate capability and specific capacity were realised in batteries with $\mathrm{Ca}^{2+}$ additives, which simultaneously exhibit preponderant maximum energy/power densities as high as $366 \mathrm{~W} \mathrm{~h} \mathrm{~kg}^{-1} @ 0.2 \mathrm{~A} \mathrm{~g}^{-1}$ and $6627 \mathrm{~W} \mathrm{~kg}^{-1} @ 10 \mathrm{~A} \mathrm{~g}^{-1}$, respectively, compared with other reported vanadium-, manganese- and Prussian blue analoguebased cathodes in the Ragone plot (Fig. 2e) [27-38].

To fully understand the electrolyte effects on the conversion reaction of $\mathrm{CaV}_{4} \mathrm{O}_{9}$ precursor and its electrochemical performance after the phase transition in the AZIB system, $\mathrm{ZnSO}_{4}$ aqueous electrolyte was also prepared for determining structural variations and electrochemical properties. Fig. S4 illustrates the battery performance with $\mathrm{ZnSO}_{4}$ electrolytes at identical conditions to compare with the same cathode materials in triflatebased aqueous electrolytes. It can be seen that the battery possesses much lower anodic oxidation potential $(1.42 \mathrm{~V})$ along with dramatic shape changes compared with others as mentioned above, which indicates an easier $\mathrm{Ca}^{2+}$ depletion or vanadyl oxidation process and unstable $\mathrm{Zn}^{2+}$ (de)intercalation processes. Additionally, GCD profiles of the batteries in $\mathrm{ZnSO}_{4^{-}}$ based aqueous electrolytes were evaluated at the current density of $0.2 \mathrm{~A} \mathrm{~g}^{-1}$ for 120 cycles (Fig. S4b). The relatively fast capacity decay (47\%), long activation process (fluctuated Coulombic efficiency $<98 \%$ during the initial 40 cycles) and low maximum specific capacity $\left(309 \mathrm{~mA} \mathrm{~h} \mathrm{~g}^{-1}\right.$ ) illustrate the poor reversibility of converted cathode materials. Meanwhile, it is worthwhile to verify whether the introduced $\mathrm{Ca}^{2+}$ additives contribute to specific capacity during the charge/discharge process. A threeelectrode configuration $\left(\mathrm{CaV}_{4} \mathrm{O}_{9} / /\right.$ porous carbon, $\mathrm{V}$ vs. $\mathrm{Ag} /$
$\mathrm{AgCl})$ with pure $0.5 \mathrm{~mol} \mathrm{~L}^{-1} \mathrm{Ca}\left(\mathrm{CF}_{3} \mathrm{SO}_{3}\right)_{2}$ electrolyte was adopted to characterize its electrochemical performance and elemental details. More specifically, Fig. S5a presents the CV profiles at a sweep rate of $0.1 \mathrm{mV} \mathrm{s}^{-1}$, in which a dramatic anodic oxidation peak occurred at the first scan and steady shapes of curves in following cycles consist with the electrolyte system using $\mathrm{CaV}_{4} \mathrm{O}_{9}$ as the cathode material. However, the feeble redox reaction peaks indicate a poor charge storage behaviour of $\mathrm{Ca}^{2+}$ species which is further verified by GCD measurement in Fig. S5b. There is an average specific capacity of $52 \mathrm{~mA} \mathrm{~h} \mathrm{~g}^{-1}$ attained in initial 10 cycles under a current density of $0.2 \mathrm{~A} \mathrm{~g}^{-1}$, which is far below that of the batteries using pure $\mathrm{Zn}\left(\mathrm{CF}_{3} \mathrm{SO}_{3}\right)_{2}$ or the mixture electrolytes. Moreover, the evolution of elemental details in Fig. S6 was observed by ex-situ SEMEDS. It is seen that only trace amount of Ca species was involved in the electrochemical reactions which is in accordance with the electrochemical evaluation.

Further investigations on electrochemical properties were conducted by galvanostatic intermittent titration technique (GITT), electrochemical impedance spectroscopy (EIS) and quantitative analysis of diffusion controlled/capacitive contributions. It is found that the $\mathrm{Zn}^{2+}$ diffusion coefficient within the converted $\mathrm{CaV}_{4} \mathrm{O}_{9}$ cathodes in both triflate-based electrolytes deliver satisfactory values in the range of $10^{-8}$ to $10^{-9} \mathrm{~cm}^{2} \mathrm{~S}^{-1}$ (Fig. S7), which is higher than previously reported values for $\mathrm{Ca}_{0.24} \mathrm{~V}_{2} \mathrm{O}_{5} \cdot 0.83 \mathrm{H}_{2} \mathrm{O}$ [15], and $\mathrm{K}_{0.25} \mathrm{~V}_{2} \mathrm{O}_{5} \cdot n \mathrm{H}_{2} \mathrm{O}$ [23] and $\mathrm{Zn}_{0.25} \mathrm{~V}_{2} \mathrm{O}_{5} \cdot n \mathrm{H}_{2} \mathrm{O}$ [27]. Notably, a relatively high ion diffusion coefficient of the batteries with $\mathrm{Ca}^{2+}$ electrolyte additives suggests improved charge transfer kinetics compared with the one in pure $\mathrm{Zn}\left(\mathrm{CF}_{3} \mathrm{SO}_{3}\right)_{2}$. Moreover, in-situ EIS characterisation before cycling and at varied (dis)charge states were also adopted to evaluate the cycle-dependant ion transport properties in 
cathode materials (Fig. S8). Pristine $\mathrm{CaV}_{4} \mathrm{O}_{9}$ in both electrolytes present the slight difference of interfacial charge transfer resistance $\left(R_{\mathrm{ct}}\right)$ with 54 and $32 \Omega$ for batteries with pure $\mathrm{Zn}\left(\mathrm{CF}_{3} \mathrm{SO}_{3}\right)_{2}$ and $\mathrm{Ca}^{2+}$ additive electrolytes, respectively, at initial state. This could be attributed to a relatively high ionic conductivity of mixed electrolytes compared with pure $\mathrm{Zn}\left(\mathrm{CF}_{3} \mathrm{SO}_{3}\right)_{2}$ electrolyte (Fig. S9d), thus strengthening the positive effect on calcium triflate additives and rendering a faster ion transport kinetics for high-rate AZIBs. Moreover, there are negligible changes of inherent ohmic resistance $\left(R_{\mathrm{s}}\right)$ in both electrolytes after cycling at varied states as can be observed from Fig. S8d, while the $R_{\mathrm{ct}}$ changes dramatically associated with different applied voltages. Interestingly, both electrodes show reduced $R_{\mathrm{ct}}$ values after the $1^{\text {st }}$ charge process, 1.8 and $4.8 \Omega$ for batteries with or without $\mathrm{Ca}^{2+}$ electrolyte additives, respectively, indicating an effective activation after the conversion reaction, which can be interpreted as improved structural and interfacial properties because of ultrathin 2D configuration with expanded interlayer space and dangling bond enriched surface with "Janus interface" derived from water bonded "pillars" and hydrated $\mathrm{V}_{2} \mathrm{O}_{5}$ sheets (more details from Raman and DFT analysis) [39]. This is also an explanation for the faster charge transfer behaviour across the solid/liquid interface in the aqueous system compared with that in non-aqueous electrolytes involving a considerable desolvation energy barrier. However, during discharge processes, the $R_{\mathrm{ct}}$ increases notably to 98 (93) and $83(105) \Omega$ at 0.75 and $0.3 \mathrm{~V}$, respectively, for batteries in $\mathrm{Ca}^{2+}$ additive (in pure $\left.\mathrm{Zn}\left(\mathrm{CF}_{3} \mathrm{SO}_{3}\right)_{2}\right)$ electrolytes. Reversibly, the $R_{\mathrm{ct}}$ can return to low values for batteries with $\mathrm{Ca}^{2+}$ additives at charge states of 0.85 and $1.7 \mathrm{~V}$, respectively, which are lower than those in pure $\mathrm{Zn}\left(\mathrm{CF}_{3} \mathrm{SO}_{3}\right)_{2}$ based batteries at identical charge states, suggesting a better interfacial charge transfer kinetics for batteries with $\mathrm{Ca}^{2+}$ additives. This phenomenon can be explained by the deposition of triflate layered double hydroxide (LDH) on the surface of cathodes as the battery discharged to the low voltage and the dissolution in the charge process together with the proton insertion/extraction, which will be observed in detail from XRD and SEM characterisations.

Additionally, we quantitatively estimated capacitive and diffusion controlled contributions from the CV curves. As shown in Fig. S10a, $86.7 \%$ of the current response can be ascribed to the capacitive charge storage process at a sweep rate of $1 \mathrm{mV} \mathrm{s}^{-1}$, which manifests a rapid electrochemical behaviour of the asprepared cathode materials in electrolytes with $\mathrm{Ca}^{2+}$ additives, contributing to superior rate capability. Similarly, the analysis was further applied to other scan rates, and the corresponding results are presented in Fig. S10b, of which an increasing fraction of capacitive response starts from $67.4 \%$ to $86.7 \%$, along with the scan rate raised from 0.1 to $1 \mathrm{mV} \mathrm{s}^{-1}$, respectively. Evidently, the electrochemical reaction rate dominates the corresponding electrode-electrolyte reaction kinetics rather than ionic diffusion rate. Furthermore, with the continuous increase of scan rates from 0.1 to $1 \mathrm{mV} \mathrm{s}^{-1}$, the $\mathrm{CV}$ profiles of batteries with $\mathrm{Ca}^{2+}$ electrolyte additives still retain their shapes, indicating a high reversibility and good reaction kinetics in comparison with the batteries in pure $\mathrm{Zn}\left(\mathrm{CF}_{3} \mathrm{SO}_{3}\right)_{2}$ electrolyte shown in Fig. S10c, e. Additionally, Fig. S10d, f show the plots of the linear relationship for $\log i v s$. $\log v$ following the equation [40]:

$i=a v^{b}$,

where the $b$ values close to 0.5 indicate the current response at the peak potential relying on semi-infinite diffusion, while the $b$ values approaching 1.0 can be interpreted as capacitive behaviour dominated charge storage. Therefore, it is obvious that the battery with $\mathrm{Ca}^{2+}$ additive electrolytes possesses $b$ values of 0.82 , $1,0.82,0.87$ for two pairs of redox peaks, respectively, in contrast to relatively low values of $0.75,0.58,0.80,0.72$ for the one in pure $\mathrm{Zn}\left(\mathrm{CF}_{3} \mathrm{SO}_{3}\right)_{2}$ electrolyte, which implies an enhanced capacitive-dominated process for batteries with $\mathrm{Ca}^{2+}$ additives.

\section{$\mathrm{Zn}^{2+} / \mathrm{H}^{+}$storage mechanism}

Based on the discussion of the variation on electrochemical behaviours of electrodes in different electrolytes and the rapid in-situ conversion upon the $1^{\text {st }}$ charge process, it is worth understanding the underlying mechanisms. Fig. 3a displays the evolution of crystal phases of $\mathrm{CaV}_{4} \mathrm{O}_{9}$ cathodes in the electrolyte with $\mathrm{Ca}^{2+}$ additives upon specific potentials during the $1^{\text {st }}$ and $5^{\text {th }}$ GCD measurement. It can be seen that the $\mathrm{CaV}_{4} \mathrm{O}_{9}$ entirely converts to a new phase after the $1^{\text {st }}$ charge process, which can be assigned to a classic vanadium bronze motif with the $\mathrm{Ca}^{2+}$ preintercalation within the $\delta-\mathrm{V}_{2} \mathrm{O}_{5}$ host (JCPDS: 88-0579), and no other impurities can be observed. Moreover, the evident diffraction peak of (001) facet at $8.0^{\circ}$ represents an interlayer space of $1.1 \mathrm{~nm}$ along the $c$-axis which is favourable for the fast $\mathrm{Zn}^{2+}$ $\left(\sim 4.3 \AA\right.$ for hydrated $\left.\mathrm{Zn}^{2+}\right)$ diffusion. It is worth noting that the (001) peak shifts towards the lower $2 \theta$ degree along with a shoulder peak upon the $1^{\text {st }}$ discharge process. The peak with relatively high Bragg diffraction angle of $6.5^{\circ}$ can be identified to an $\mathrm{LDH}$ phase of $\mathrm{Zn}_{x}(\mathrm{OTf})_{y}(\mathrm{OH})_{2 x-y} \cdot n \mathrm{H}_{2} \mathrm{O}$, which was widely proved by $\mathrm{MnO}_{2}$-based cathodes using triflate electrolytes in AZIBs, but rarely reported for vanadium bronze cathodes $[10,41]$. Recent research discovered that the formation of $\mathrm{LDH}$ could also occur in vanadium oxide-based cathodes, which is usually associated with the co-insertion of proton and $\mathrm{Zn}^{2+}$, thus resulting in the rise of the local $\mathrm{pH}$ [42]. Meanwhile, another peak at $2 \theta$ of $6.0^{\circ}$ indicated the enlarged interplanar spacing of $14.6 \AA$ owing to more accommodated charge carriers within the interplanar, which is in consistency with reported $\mathrm{Zn}_{3} \mathrm{~V}_{2} \mathrm{O}_{7}$ $(\mathrm{OH})_{2} \cdot 2 \mathrm{H}_{2} \mathrm{O}$ [36], $\mathrm{Li}_{x} \mathrm{~V}_{2} \mathrm{O}_{5} \cdot n \mathrm{H}_{2} \mathrm{O}$ [43] and $\mathrm{V}_{5} \mathrm{O}_{12} \cdot 6 \mathrm{H}_{2} \mathrm{O}$ [44]. XRD measurements at the $5^{\text {th }}$ GCD cycle also preserve the same shift tendency as observed in the $1^{\text {st }}$ discharge process, where the (001) peak gradually evolves and swifts to $6.1^{\circ}$ at the $5^{\text {th }}$ discharge state, and then recovers to its initial position $\left(7.9^{\circ}\right)$ at the $5^{\text {th }}$ charge state with negligible changes compared with that of the $1^{\text {st }}$ charge/discharge states, suggesting a highly reversible phase evolution. Comparably, the ex-situ XRD analyses of $\mathrm{CaV}_{4} \mathrm{O}_{9}$ batteries with the pure $\mathrm{ZnSO}_{4}$ and $\mathrm{Zn}\left(\mathrm{CF}_{3} \mathrm{SO}_{3}\right)_{2}$ electrolytes exhibit identical evolution tendency of diffraction peaks upon (dis)charge steps, respectively (Figs S4c and S9a). However, there are new phases emerging in $\mathrm{ZnSO}_{4}$ electrolytes, which can be indexed to $\mathrm{CaSO}_{4} \cdot 2 \mathrm{H}_{2} \mathrm{O}$ (ICSD: 70-0982) and $\mathrm{Zn}_{4} \mathrm{SO}_{4}(\mathrm{OH})_{6} \cdot 3 \mathrm{H}_{2} \mathrm{O}$ (ICSD: 78-0247). Specifically, the reason for the formation of $\mathrm{Zn}_{4} \mathrm{SO}_{4}(\mathrm{OH})_{6} \cdot 3 \mathrm{H}_{2} \mathrm{O}$ is the same as the electrodes in triflate-based electrolytes, and it can gradually vanish with the increase of the applied voltage and reappear during the discharge process. More interestingly, the crystal phase of converted $\mathrm{CaV}_{4} \mathrm{O}_{9}$ at the charged state is more likely to be $\mathrm{V}_{5} \mathrm{O}_{12} \cdot 6 \mathrm{H}_{2} \mathrm{O}$ (JCPDS: 45-1401), which also possesses layered frameworks built by coordinated $\mathrm{VO}_{x}$ polyhedron without preintercalated species. These phenomena can be assumed that entire $\mathrm{Ca}^{2+}$ in pristine $\mathrm{CaV}_{4} \mathrm{O}_{9}$ were extracted by $\mathrm{SO}_{4}{ }^{2-}$ resulting in an insoluble by-product $\left(\mathrm{CaSO}_{4} \cdot 2 \mathrm{H}_{2} \mathrm{O}\right)$ along with the dra- 

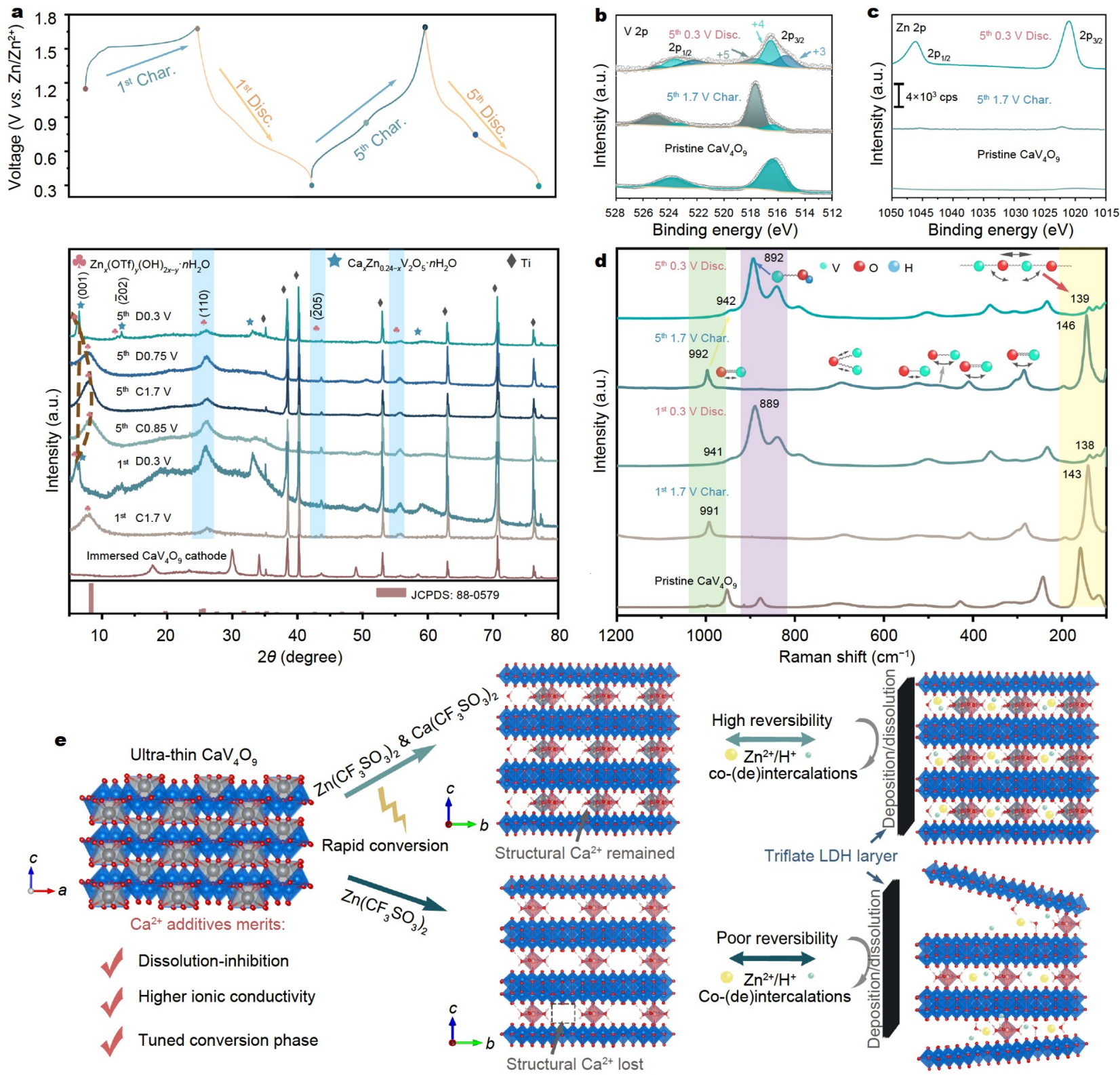

Figure 3 Characterisation of electrodes with additives in terms of (a) ex-situ XRD measurement of cathodes during different stages of the $1^{\text {st }}$ and $5^{\text {th }}$ charge/ discharge cycles, respectively; ex-situ XPS characterisation of pristine and cycled $\mathrm{CaV}_{4} \mathrm{O}_{9}$ for determining core-level spectra of (b) V 2p and (c) Zn $2 p$ states, respectively; (d) ex-situ Raman spectra of cathodes upon different (dis)charge processes; (e) schematic diagram of converted cathodes in two electrolytes along with varied electrochemical/structural behaviours during $\mathrm{Zn}^{2+} / \mathrm{H}^{+}$co-insertion/extraction.

matic phase transformation, which may also account for the relatively low anodic oxidation potential in the CV profile compared with the other two control groups during the $1^{\text {st }}$ charge process. Additionally, the depletion of interplanar $\mathrm{Ca}^{2+}$ in layered open frameworks gives rise to unstable structural features and poor electrochemical properties which can be interpreted as unsatisfactory battery cycling performance and notable cathode dissolution (Fig. S4d). Indeed, it is seen that there are visually coloured substances on the dissembled separators which can be ascribed to dissolved vanadium species involving battery redox reactions (green/yellow stands for $\mathrm{V}^{4+/ 5+}$, and dark green/ black refers to $\mathrm{V}^{3+}$ ). Furthermore, the magnified XRD diffraction regions of (001) plane in all three control groups at the $1^{\text {st }}$ charge state are presented in Fig. S9b, of which both batteries in pure
$\mathrm{Zn}\left(\mathrm{CF}_{3} \mathrm{SO}_{3}\right)_{2}$ and $\mathrm{ZnSO}_{4}$ electrolytes present relatively low diffraction angles $\left(7.8^{\circ}\right.$ and $7.7^{\circ}$ for $\mathrm{Zn}\left(\mathrm{CF}_{3} \mathrm{SO}_{3}\right)_{2}$ and $\mathrm{ZnSO}_{4}$ electrolytes, respectively) compared with the one $\left(8^{\circ}\right)$ in $\mathrm{Zn}\left(\mathrm{CF}_{3} \mathrm{SO}_{3}\right)_{2}$ with $\mathrm{Ca}^{2+}$ electrolyte additives. The result can be explained by the deficiency of pre-inserted $\mathrm{Ca}^{2+}$ resulting in the lack of hydrogen bond against the interlayer electrostatic repulsion accompanied by dramatic phase transition [45], which can be further verified by the elemental analysis. Therefore, the $\mathrm{Ca}^{2+}$ triflate additive can be regarded as a crucial factor to develop distinct converted phase from $\mathrm{CaV}_{4} \mathrm{O}_{9}$ with better structural evolution properties. XPS results in Fig. 3b, c illustrate the variation of chemical states for $\mathrm{V} 2 \mathrm{p}$ and $\mathrm{Zn} 2 \mathrm{p}$ in pristine $\mathrm{CaV}_{4} \mathrm{O}_{9}$ and its cycled states with $\mathrm{Ca}^{2+}$ electrolyte additives. As for the core-level of $\mathrm{V} 2 \mathrm{p}$ spectra, the original $\mathrm{CaV}_{4} \mathrm{O}_{9}$ only 
possesses $\mathrm{V}^{4+}$ species with a binding energy of $516.4 \mathrm{eV}$ for $\mathrm{V} 2 \mathrm{p}_{3 / 2}$. Nevertheless, at fully charged states $(1.7 \mathrm{~V})$, a strong and sharp peak occurs at $517.6 \mathrm{eV}$ for $\mathrm{V} 2 \mathrm{p}_{3 / 2}$ with an average valence state of 4.78 , which is in accordance with other reported vanadium bronze [15], indicating the deintercalation of $\mathrm{Zn}^{2+}$ and $\mathrm{H}^{+}$ associated with the oxidation of host materials [27]. Inversely, the oxidised vanadium species can be reversibly reduced as observed by the attenuated intensity of $\mathrm{V}^{4+/ 5+}$ components, and an emerging peak locates at $515.4 \mathrm{eV}$ referring to $\mathrm{V}^{3+} 2 \mathrm{p}_{3 / 2}$, which is in agreement with the previous study [46]. Furthermore, there is no trace of $\mathrm{Zn}$ signals detected in the original $\mathrm{CaV}_{4} \mathrm{O}_{9}$, while a substantive peak appearing indicates inserted $\mathrm{Zn}^{2+}$ species. After a fully charged process, the majority of $\mathrm{Zn}^{2+}$ species were extracted from the lattice, and the lattice-trapped or surface-adsorbed $\mathrm{Zn}^{2+}$ species could contribute to the corresponding weak signals [47].

Moreover, we further performed ex-situ Raman analysis of $\mathrm{CaV}_{4} \mathrm{O}_{9}$ cathodes and the cycled electrodes in $\mathrm{Zn}\left(\mathrm{CF}_{3} \mathrm{SO}_{3}\right)_{2}$ electrolytes with or without $\mathrm{Ca}^{2+}$ additives. As shown in Fig. $3 \mathrm{~d}$ and Fig. S9c, several typical features can be identified to reveal the structural information of the as-obtained vanadium bronzes. More specifically, low-frequency stretching vibration modes in the range of $100-200 \mathrm{~cm}^{-1}$ can be assigned to relative translational motions of $\mathrm{VO}_{x}$ bilayer in a unit cell involving with particular vanadyl bonds in $\mathrm{VO}_{x}$ octahedra [48]. Hence, the intensified signals of pristine and fully charged electrodes at this region reflect a long-range order of in-plane $a b$ orientation in the $\left[\mathrm{V}_{x} \mathrm{O}_{y}\right]$ sheets, which is crucial for the evaluation of local symmetry in layered structures [49]. Other labelled bands in the range of $850-200 \mathrm{~cm}^{-1}$ in charged electrodes can be assigned to $\mathrm{V}-\mathrm{O}-\mathrm{V}$ anti-symmetric stretching mode $\left(\sim 695 \mathrm{~cm}^{-1}\right.$, bridging $\mathrm{O}$ coordinated with two corner-sharing vanadyl polyhedra), stretching mode of $\mathrm{V}-\mathrm{O}\left(\sim 525 \mathrm{~cm}^{-1}\right.$, inter-chain bond), bending vibration mode of $\mathrm{V}-\mathrm{O}-\mathrm{V}$ bridge $\left(\sim 475 \mathrm{~cm}^{-1}\right.$, in-plane cornersharing $\mathrm{O}$ coordinated with centre $\mathrm{V})$ and rocking oscillation ( $\sim 407$ and $\sim 283 \mathrm{~cm}^{-1}$, involving with apical oxygen and centre V) following an order from the highest to the lowest frequency $[48,50]$. Particularly, the band around $\sim 991 \mathrm{~cm}^{-1}$ stands for the stretching mode of the shortest bond in vanadyl polyhedron, $\mathrm{V}=\mathrm{O}$ (apical $\mathrm{O}$ double-bonded with the centre $\mathrm{V}$ ), which is sensitive to structural changes upon the (de)intercalation process [51]. For instance, with the increase of the inserted content of $\mathrm{Li}^{+}$ in $\mathrm{V}_{2} \mathrm{O}_{5}$ framework, the band shows the red shift representing lengthening bond because of introduced foreign species within the interplanar, and vice versa $[48,51]$. In contrast to Raman spectra of charged states, it is found that numerous changes in fully discharged $(0.3 \mathrm{~V})$ electrodes are due to regular red shifts of vibration modes to lower Raman shifts, suggesting the lengthening bonds induced by $\mathrm{Zn}^{2+} / \mathrm{H}^{+}$co-insertion. The results can be corresponded to the expanded lattice from the XRD results at the discharged state. Moreover, it should be noted that there is no concrete verdict of the strong bond with Raman shifts at $\sim 890 \mathrm{~cm}^{-1}$ in discharged electrodes. However, it was observed and assumed from the previous work that this bond generally exists in hydrated $\mathrm{V}_{2} \mathrm{O}_{5}$ implying water-governed properties $[52,53]$. Considering the same characteristic peak in Raman spectra from the reported hydrated vanadium bronze [47], we can speculate that it derives from the coordination of water/ hydronium with $\mathrm{V}=\mathrm{O}$ by hydrogen bond, further confirming the co-insertion mechanism. Similarly, the Raman spectra of pure $\mathrm{Zn}\left(\mathrm{CF}_{3} \mathrm{SO}_{3}\right)_{2}$ group also exhibit analogical features in Fig. S9c.
All identified Raman signals can be observed with varying extent of offset especially for the cycled electrodes, that is, relatively large Raman shift $\left(4 \mathrm{~cm}^{-1}\right)$ of $\mathrm{V}=\mathrm{O}$ bond to higher frequency and relatively low transitional vibration mode of $\mathrm{V}_{2} \mathrm{O}_{5}$ bilayer $\left(143 \mathrm{~cm}^{-1}\right)$ after $5 \mathrm{GCD}$ cycles compared with those with $\mathrm{Ca}^{2+}$ electrolyte additives, indicating the loss of "pillar" ions and the intensive long-range disorder. Meanwhile, this can be also verified by an additional peak emerging at $919 \mathrm{~cm}^{-1}$ in the fully charged state with pure $\mathrm{Zn}\left(\mathrm{CF}_{3} \mathrm{SO}_{3}\right)_{2}$ electrolyte, suggesting an irreversible structure formed after the cycling process. In addition to structural and chemical states variation, it should be emphasised that there are negligible changes from the AFM measurement and the thickness after the conversion reaction, which still maintains a capability to facilitate the charge diffusion in ultra-thin 2D structures (Fig. S11).

To understand the structural variations during cycling states of the two electrodes in different electrolytes, the EDS elemental analyses of the $1^{\text {st }}$ fully charged cathode in two triflate control groups were also performed, as shown in Fig. S12a, b. The relatively high ratio of $\mathrm{Ca}: \mathrm{V}$ for electrodes treated with electrolyte additives compared with pure $\mathrm{Zn}\left(\mathrm{CF}_{3} \mathrm{SO}_{3}\right)_{2}$ was not only detected by large scale measurement, but also verified by the TEM-EDS characterisation on a small region of materials without the interference by the residue of electrolytes and other impurities (Fig. S12c). Accordingly, the calculated chemical formulas of $\mathrm{Ca}_{0.1} \mathrm{Zn}_{0.14} \mathrm{~V}_{2} \mathrm{O}_{5} \cdot n \mathrm{H}_{2} \mathrm{O}$ and $\mathrm{Ca}_{0.02} \mathrm{Zn}_{0.07} \mathrm{~V}_{2} \mathrm{O}_{5} \cdot n \mathrm{H}_{2} \mathrm{O}$ were attained for $1^{\text {st }}$ charged electrodes in additive electrolytes and pure $\mathrm{Zn}\left(\mathrm{CF}_{3} \mathrm{SO}_{3}\right)_{2}$, respectively, that is, nearly all structural $\mathrm{Ca}^{2+}$ ions were lost after the initial conversion for the electrode without $\mathrm{Ca}^{2+}$ additives in electrolyte. Interestingly, it is further verified that the $\mathrm{LDH}$ layer shields on cathode surfaces in both triflate-based electrodes at charged states (Fig. S12d, e). However, it is more dense and prominent in pure $\mathrm{Zn}\left(\mathrm{CF}_{3} \mathrm{SO}_{3}\right)_{2}$ electrolyte which could be assumed as more dramatic local $\mathrm{pH}$ fluctuations (pristine $\mathrm{pH}$ for pure $\mathrm{Zn}\left(\mathrm{CF}_{3} \mathrm{SO}_{3}\right)_{2}$ and $\mathrm{Ca}^{2+}$ additives electrolytes are 3.81 and 4.17 , respectively) during the coinsertion process, since the precipitation of triflate LDH layer occurs at the $\mathrm{pH}$ of $\sim 5.2$ [42]. Following STEM measurements of cycled cathode materials with $\mathrm{Ca}^{2+}$ additives clearly illustrate the lattice fringe evolution upon fully (dis)charge treatments along with the elemental mapping detections (Fig. S13), which agrees with the previous discussion on structural and chemical variations.

Remarkably, we utilised Swagelok-cells and the inductively coupled plasma-optical emission spectrometry (ICP-OES) to evaluate ex-situ elemental information for the cycled electrodes in triflate-based electrolytes (Fig. S14). The results reveal that the dissolution of cathode materials was successfully suppressed by $\mathrm{Ca}^{2+}$ additives via the comparison of vanadium species in aqueous electrolytes, which could be interpreted by Le Chatelier's principle. Therefore, the merits of additive-involved electrolytes can be summarised as high ionic conductivity, tuneable structural conversion and the suppression of the dissolution, which are essential for maintaining the outstanding electrochemical activity of cathode materials (Fig. 3e). Additionally, it is worth noting that the electrolyte-manipulated $\mathrm{CaV}_{4} \mathrm{O}_{9}$ conversion behaviors are not limited to $\mathrm{Zn}$ and $\mathrm{Ca}$ triflate electrolytes, but also suitable for other triflate-based systems for generating varied dual-ion pre-intercalated $\mathrm{V}_{2} \mathrm{O}_{5}$ cathodes. As a proof of concept, it was verified that pristine $\mathrm{CaV}_{4} \mathrm{O}_{9}$ cathode can be rapidly converted to $\mathrm{Ca}_{0.13} \mathrm{Mg}_{0.07} \mathrm{~V}_{2} \mathrm{O}_{5} \cdot n \mathrm{H}_{2} \mathrm{O}$ in $3 \mathrm{~mol} \mathrm{~L}^{-1}$ 
$\mathrm{Mg}\left(\mathrm{CF}_{3} \mathrm{SO}_{3}\right)_{2}$ and $0.5 \mathrm{~mol} \mathrm{~L}^{-1} \mathrm{Ca}\left(\mathrm{CF}_{3} \mathrm{SO}_{3}\right)_{2}$ aqueous electrolyte after the $1^{\text {st }}$ charge process (Figs $\mathrm{S} 15$ and S16). Hence, the generation of other vanadium bronzes can be realised by the method from this study, which could be applied to different battery systems for designing adequate cathode materials.

\section{Computational analysis}

The deep insight of structural and electronic benefits of the converted $\mathrm{CaV}_{4} \mathrm{O}_{9}$ (involved $\mathrm{Ca}^{2+}$ additives) for charge storage was analysed by DFT calculations. For the geometric construction of the converted product, $\mathrm{Ca}_{0.12} \mathrm{Zn}_{0.12} \mathrm{~V}_{2} \mathrm{O}_{5} \cdot n \mathrm{H}_{2} \mathrm{O}$, the geometric construction of $\mathrm{Ca}_{0.24} \mathrm{~V}_{2} \mathrm{O}_{5} \cdot n \mathrm{H}_{2} \mathrm{O}$ is adopted as the prototype to substitute half of $\mathrm{Ca}$ atoms in a $1 \times 3 \times 1$ supercell. All potential structures of $\mathrm{Ca}_{0.12} \mathrm{Zn}_{0.12} \mathrm{~V}_{2} \mathrm{O}_{5} \cdot n \mathrm{H}_{2} \mathrm{O}$ were also considered to determine the most stable structure, as shown in
Fig. $4 \mathrm{a}$ and Fig. S17. The $\mathrm{Ca}_{0.12} \mathrm{Zn}_{0.12} \mathrm{~V}_{2} \mathrm{O}_{5} \cdot n \mathrm{H}_{2} \mathrm{O}$ crystallizes with a space group symmetry of $C 2 / m$; the lattice parameter $a$ is equal to $11.679 \AA, b$ is equal to $10.962 \AA$, and $c$ is equal to $10.986 \AA$. The $\mathrm{Ca}$ and $\mathrm{Zn}$ ions in $\mathrm{Ca}_{0.12} \mathrm{Zn}_{0.12} \mathrm{~V}_{2} \mathrm{O}_{5} \cdot n \mathrm{H}_{2} \mathrm{O}$ prefer to insert in the interlayer of $\mathrm{V}_{2} \mathrm{O}_{5}$ bilayer and both could bind with the structural water to form $\mathrm{ZnO}_{6}$ and $\mathrm{CaO}_{7}$ polyhedra. More importantly, the structural water could accelerate the diffusion of $\mathrm{Zn}^{2+}$, which is also proved by the previous study for its lubricant effect. The structural water can reconstruct a smooth electrostatic environment by the charge shielding effect for the $\mathrm{Zn}^{2+}$ movement [54]. These pre-inserted $\mathrm{Ca}$ and $\mathrm{Zn}$ ions increased the concentration of the structural water and thus effectively increased the diffusion coefficient of the $\mathrm{Ca}_{0.12} \mathrm{Zn}_{0.12^{-}}$ $\mathrm{V}_{2} \mathrm{O}_{5} \cdot n \mathrm{H}_{2} \mathrm{O}$. Typically, in $\mathrm{CaO}_{7}$ polyhedron, $\mathrm{Ca}$ binds with three $\mathrm{O}_{(\mathrm{V})}$ from $\mathrm{VO}_{x}$ octahedrons. The $\mathrm{Ca}-\mathrm{O}_{(\mathrm{v})}$ bond lengths, whose $\mathrm{O}$ a

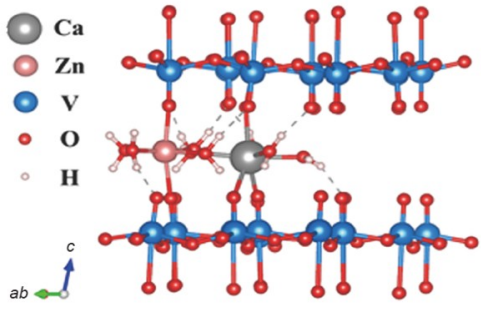

b

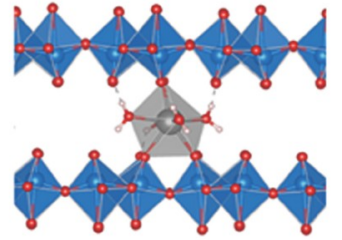

$\mathrm{Ca}_{0.12} \mathrm{~V}_{2} \mathrm{O}_{5} \cdot n \mathrm{H}_{2} \mathrm{O}$

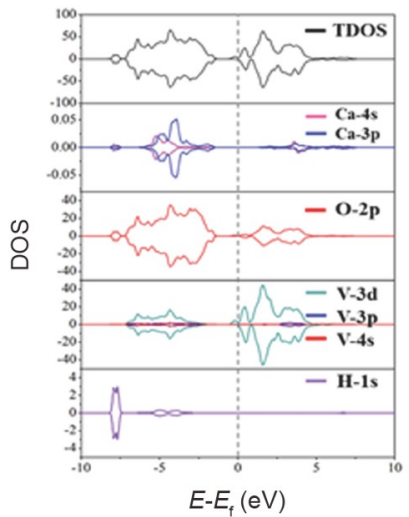

c

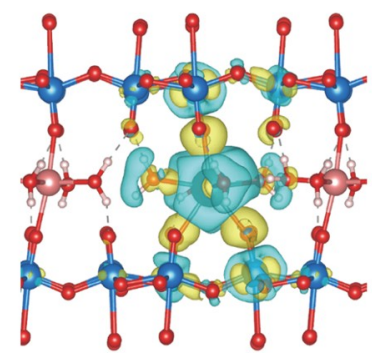

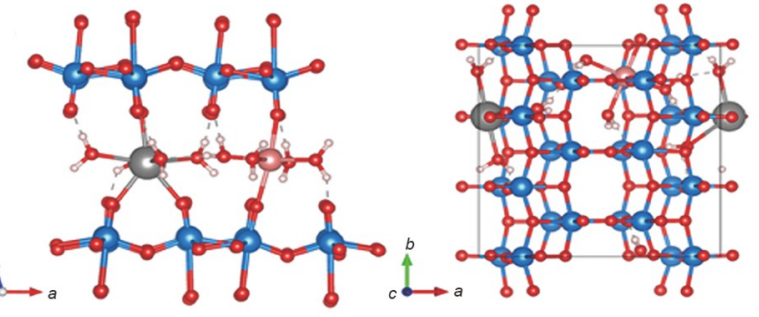
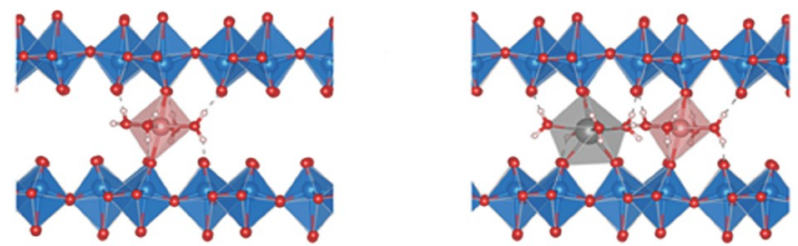

$\mathrm{Zn}_{0.12} \mathrm{~V}_{2} \mathrm{O}_{5} \cdot n \mathrm{H}_{2} \mathrm{O}$

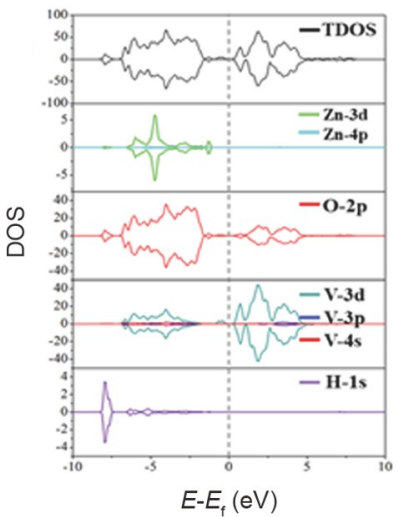

$\mathrm{Ca}_{0.12} \mathrm{Zn}_{0.12} \mathrm{~V}_{2} \mathrm{O}_{5} \cdot n \mathrm{H}_{2} \mathrm{O}$

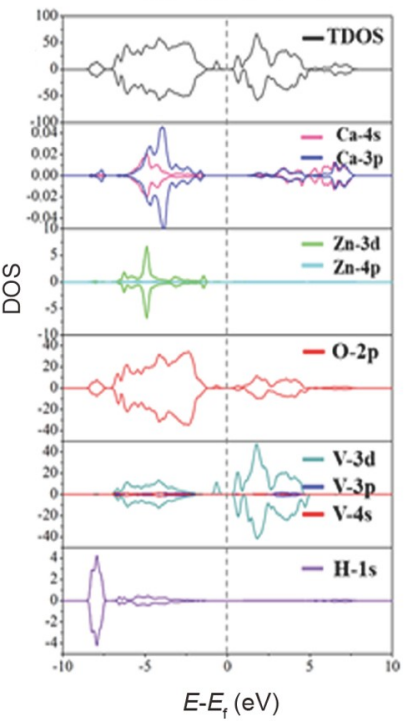

Figure 4 (a) The most stable geometric construction of $\mathrm{Ca}_{0.12} \mathrm{Zn}_{0.12} \mathrm{~V}_{2} \mathrm{O}_{5}$, viewed along the $a$-, $b$-, and $c$-axes. The grey, pink, blue, red, and pink spheres refer to $\mathrm{Ca}, \mathrm{Zn}, \mathrm{V}, \mathrm{O}$, and $\mathrm{H}$ atoms, respectively. (b) Crystal structures and the corresponding $\mathrm{DOS}$ for $\mathrm{Ca}_{0.12} \mathrm{~V}_{2} \mathrm{O}_{5} \cdot n \mathrm{H}_{2} \mathrm{O}, \mathrm{Zn}_{0.12} \mathrm{~V}_{2} \mathrm{O}_{5} \cdot n \mathrm{H}_{2} \mathrm{O}$, and $\mathrm{Ca}_{0.12} \mathrm{Zn}_{0.12} \mathrm{~V}_{2} \mathrm{O}_{5}$ $\cdot n \mathrm{H}_{2} \mathrm{O}$, respectively. The grey dashed lines showing Fermi levels. (c) The differential charge density diagram of $\mathrm{Ca}_{0.12} \mathrm{Zn}_{0.12} \mathrm{~V}_{2} \mathrm{O}_{5} \cdot n \mathrm{H}_{2} \mathrm{O}$. The blue regions represent the charge reduction, while the yellow regions represent the charge accumulation. The iso-surface was set to 0.0003 e $\AA^{-3}$. 
is also bonded with $\mathrm{V}$, are in the range of $2.35-2.46 \AA$. The average bond length of $\mathrm{Ca}-\mathrm{O}$ in $\mathrm{CaO}_{7}$ polyhedron is $2.41 \AA$. Those $\mathrm{Ca}-\mathrm{O}_{(\mathrm{V})}$ bonds mean stronger binding force along the $c$ axis than van der Waals forces of the $\mathrm{V}_{2} \mathrm{O}_{5}$ bilayer. Though $\mathrm{Zn}$ binds with less $\mathrm{O}_{(\mathrm{V})}$, the substitution with $\mathrm{Zn}$ could also stabilize $\mathrm{V}_{2} \mathrm{O}_{5}$ bilayer as explained before. The $\mathrm{Zn}-\mathrm{O}_{(\mathrm{V})}$ bond lengths are 2.13 and $2.24 \AA$, which approach the lengths of the $\mathrm{V}-\mathrm{O}$ bond in $\mathrm{V}_{2} \mathrm{O}_{5}$. Besides, the $\mathrm{ZnO}_{6}$ octahedron is similar to $\mathrm{VO}_{6}$ octahedron in $\mathrm{V}_{2} \mathrm{O}_{5}$ layers.

There is quite a lot of synergy for such a small distance of $5.50 \AA$ between $\mathrm{Ca}$ and $\mathrm{Zn}$ ions. Thus, we calculated $\mathrm{Ca}_{0.12} \mathrm{~V}_{2} \mathrm{O}_{5}$. $n \mathrm{H}_{2} \mathrm{O}$ to illustrate the interaction between $\mathrm{Ca}$ and $\mathrm{Zn}$ ions. The $\mathrm{Ca}-\mathrm{O}_{(\mathrm{v})}$ bond lengths in $\mathrm{Ca}_{0.12} \mathrm{~V}_{2} \mathrm{O}_{5} \cdot n \mathrm{H}_{2} \mathrm{O}$ are longer than those in $\mathrm{Ca}_{0.12} \mathrm{Zn}_{0.12} \mathrm{~V}_{2} \mathrm{O}_{5} \cdot n \mathrm{H}_{2} \mathrm{O}$, which are in the range from 2.42-2.52 $\AA$. The intercalation of $\mathrm{Zn}^{2+}$ effectively facilitates the bonding of $\mathrm{Ca}$ and $\mathrm{O}_{(\mathrm{V})}$, thus further strengthening the framework consisting of $\mathrm{CaO}_{7}$ polyhedron, $\mathrm{ZnO}_{6}$ polyhedron, and $\mathrm{V}_{2} \mathrm{O}_{5}$ layers to avoid the structural failure of the $\mathrm{V}_{2} \mathrm{O}_{5}$ host $[23,27]$.

To further understand the electronic structure of $\mathrm{Ca}_{0.12} \mathrm{Zn}_{0.12-}$ $\mathrm{V}_{2} \mathrm{O}_{5}$, the corresponding partial density of states (DOS) of $\mathrm{Ca}_{0.12} \mathrm{~V}_{2} \mathrm{O}_{5} \cdot n \mathrm{H}_{2} \mathrm{O}, \mathrm{Zn}_{0.12} \mathrm{~V}_{2} \mathrm{O}_{5} \cdot n \mathrm{H}_{2} \mathrm{O}$, and $\mathrm{Ca}_{0.12} \mathrm{Zn}_{0.12} \mathrm{~V}_{2} \mathrm{O}_{5} \cdot n \mathrm{H}_{2} \mathrm{O}$ are illustrated in Fig. $4 \mathrm{~b}$. For these materials, the valence and conduction bands are mainly contributed from the $2 p$ orbitals of $\mathrm{O}$ and $3 \mathrm{~d}$ orbitals of $\mathrm{V}$ ions in the $\mathrm{V}_{2} \mathrm{O}_{5}$ bilayer. Based on the comparison of the DOS of $\mathrm{Ca}_{0.12} \mathrm{~V}_{2} \mathrm{O}_{5} \cdot n \mathrm{H}_{2} \mathrm{O}$ with that of calculated $\mathrm{V}_{2} \mathrm{O}_{5} \cdot n \mathrm{H}_{2} \mathrm{O}$ [54], the Ca-ion intercalation made total DOS (TDOS) shift below the Fermi level along with the reduction of $\mathrm{V}_{2} \mathrm{O}_{5}$. The isolated peak near the Fermi level mainly comes from the contribution of $\mathrm{V}$ in $\mathrm{V}_{2} \mathrm{O}_{5}$, implying electron transfer of $\mathrm{Ca}$ to the $\mathrm{V}$. This reduction of $\mathrm{V}$ in $\mathrm{V}_{2} \mathrm{O}_{5}$ also further increased electrical conductivity than the one without the Ca-ion intercalation. On the other hand, the more reduced $\mathrm{V}$ in $\mathrm{V}_{2} \mathrm{O}_{5}$ enhanced the activities during charge and discharge processes. The differential charge density diagram of $\mathrm{Ca}$ in $\mathrm{Ca}_{0.12} \mathrm{Zn}_{0.12} \mathrm{~V}_{2} \mathrm{O}_{5} \cdot n \mathrm{H}_{2} \mathrm{O}$ has also been visualised in Fig. $4 \mathrm{c}$. The blue regions mean the charge reduction, while the yellow regions mean the charge accumulation. Thus, there is an obvious charge transfer occurring between $\mathrm{Ca}$, structural water, and $\mathrm{V}_{2} \mathrm{O}_{5}$ layers. Those blue regions around $\mathrm{Ca}$ imply that $\mathrm{Ca}$ loses considerable charges while the nearby $\mathrm{V}$ and $\mathrm{O}$ obtain electrons from $\mathrm{Ca}$ corresponding to the yellow region around them. Based on the comparison of the DOS of $\mathrm{Ca}_{0.12} \mathrm{~V}_{2} \mathrm{O}_{5} \cdot n \mathrm{H}_{2} \mathrm{O}$ with that of calculated $\mathrm{V}_{2} \mathrm{O}_{5} \cdot n \mathrm{H}_{2} \mathrm{O}$ [54], the $\mathrm{Zn}$-ion intercalation made TDOS in Fig. $4 \mathrm{~b}$ shift below the Fermi level more than Ca-ion intercalation, forming strong interaction of $\mathrm{Zn}-\mathrm{O}_{(\mathrm{V})}$ bond with shorter bond lengths. The newly formed peak is further away from the Fermi level and the electronic conductivity is lower than that of $\mathrm{Ca}_{0.12} \mathrm{~V}_{2} \mathrm{O}_{5} \cdot n \mathrm{H}_{2} \mathrm{O}$. However, it does enhance the electrochemical activity but not as obvious as Ca pre-accommodated $\mathrm{V}_{2} \mathrm{O}_{5}$. The differential charge density diagram of $\mathrm{Zn}$ in $\mathrm{Ca}_{0.12} \mathrm{Zn}_{0.12} \mathrm{~V}_{2} \mathrm{O}_{5}$. $n \mathrm{H}_{2} \mathrm{O}$ has also been visualised in Fig. S18. As for $\mathrm{Ca}_{0.12} \mathrm{Zn}_{0.12} \mathrm{~V}_{2} \mathrm{O}_{5} \cdot n \mathrm{H}_{2} \mathrm{O}, \mathrm{Zn}$ and $\mathrm{Ca}$ co-intercalation both enhance the electrochemical activity and electronic conductivity for transferring electrons to $\mathrm{V}$ within $\mathrm{V}_{2} \mathrm{O}_{5}$ bilayers. Hence, the capability of $\mathrm{Ca}_{0.12} \mathrm{Zn}_{0.12} \mathrm{~V}_{2} \mathrm{O}_{5} \cdot n \mathrm{H}_{2} \mathrm{O}$ as cathode materials for AZIBs has been greatly enhanced.

\section{CONCLUSION}

In-situ electrochemical conversion of quasi-2D ultra-thin $\mathrm{CaV}_{4} \mathrm{O}_{9}$ to novel vanadium bronze, $\mathrm{Ca}_{0.12} \mathrm{Zn}_{0.12} \mathrm{~V}_{2} \mathrm{O}_{5} \cdot n \mathrm{H}_{2} \mathrm{O}$, has been demonstrated as an effective strategy for high-performance AZIBs via comprehensive studies on analytical techniques and structural/chemical characterisations in different electrolyte systems. In particular, the $\mathrm{Ca}^{2+}$ additive plays a vital role in not only enhancing the ionic conductivity, but also preserving the layered structure of $\delta-\mathrm{V}_{2} \mathrm{O}_{5}$ and avoiding structural collapse and dissolution after the conversion with pre-intercalated $\mathrm{Ca}^{2+}$ and $\mathrm{Zn}^{2+}$. Additionally, through DFT calculations, the structural and electronic advantages of $\mathrm{Ca}_{0.12} \mathrm{Zn}_{0.12} \mathrm{~V}_{2} \mathrm{O}_{5} \cdot n \mathrm{H}_{2} \mathrm{O}$ were elucidated as reinforced charge screen/pillar synergistic effects and electron transportation, which convincingly support the experimental results such as high rate capability of $51.3 \%$ capacity retention after fifty-fold current density increase $\left(0.2\right.$ to $\left.10 \mathrm{~A} \mathrm{~g}^{-1}\right)$, reversible specific capacity of $478 \mathrm{~mA} \mathrm{~h} \mathrm{~g}^{-1} @ 0.2 \mathrm{~A} \mathrm{~g}^{-1}$, robust stability of $\sim 24 \%$ capacity attenuation after 3000 cycles at $10 \mathrm{~A} \mathrm{~g}^{-1}$. Thus, it is believed that this study will shed lights on the design of other in-situ converted cathodes for $\mathrm{Zn}$-ion batteries.

\section{Received 25 August 2021; accepted 4 November 2021; published online 6 January 2022}

1 Martin G, Rentsch L, Höck M, et al. Lithium market research-Global supply, future demand and price development. Energy Storage Mater, 2017, 6: 171-179

2 Palacín MR, de Guibert A. Why do batteries fail? Science, 2016, 351: 6273

3 Posada JOG, Rennie AJR, Villar SP, et al. Aqueous batteries as grid scale energy storage solutions. Renew Sustain Energy Rev, 2017, 68: $1174-1182$

4 Liu C, Xie X, Lu B, et al. Electrolyte strategies toward better zinc-ion batteries. ACS Energy Lett, 2021, 6: 1015-1033

5 Liu Z, Huang Y, Huang Y, et al. Voltage issue of aqueous rechargeable metal-ion batteries. Chem Soc Rev, 2020, 49: 180-232

6 Dong H, Li J, Guo J, et al. Insights on flexible zinc-ion batteries from lab research to commercialization. Adv Mater, 2021, 33: 2007548

7 Huang J, Li Y, Xie R, et al. Structural engineering of cathodes for improved Zn-ion batteries. J Energy Chem, 2021, 58: 147-155

8 Liu Y, He G, Jiang H, et al. Cathode design for aqueous rechargeable multivalent ion batteries: Challenges and opportunities. Adv Funct Mater, 2021, 31: 2010445

9 Tang B, Shan L, Liang S, et al. Issues and opportunities facing aqueous zinc-ion batteries. Energy Environ Sci, 2019, 12: 3288-3304

10 Blanc LE, Kundu D, Nazar LF. Scientific challenges for the implementation of $\mathrm{Zn}$-ion batteries. Joule, 2020, 4: 771-799

11 Yang Q, Mo F, Liu Z, et al. Activating C-coordinated iron of iron hexacyanoferrate for $\mathrm{Zn}$ hybrid-ion batteries with 10000 -cycle lifespan and superior rate capability. Adv Mater, 2019, 31: 1901521

$12 \mathrm{Li} \mathrm{H}, \mathrm{Ma} \mathrm{L}, \mathrm{Han} \mathrm{C}$, et al. Advanced rechargeable zinc-based batteries: Recent progress and future perspectives. Nano Energy, 2019, 62: 550587

13 Gao J, Xie X, Liang S, et al. Inorganic colloidal electrolyte for highly robust zinc-ion batteries. Nano-Micro Lett, 2021, 13: 69

14 Doughty DH, Butler PC, Akhil AA, et al. Batteries for large-scale stationary electrical energy storage. Electrochem Soc Interface, 2010, 19: 49-53

15 Xia C, Guo J, Li P, et al. Highly stable aqueous zinc-ion storage using a layered calcium vanadium oxide bronze cathode. Angew Chem Int Ed, 2018, 57: 3943-3948

16 Fang G, Zhou J, Pan A, et al. Recent advances in aqueous zinc-ion batteries. ACS Energy Lett, 2018, 3: 2480-2501

17 Yang $\mathrm{Y}$, Tang $\mathrm{Y}$, Liang S, et al. Transition metal ion-preintercalated $\mathrm{V}_{2} \mathrm{O}_{5}$ as high-performance aqueous zinc-ion battery cathode with broad temperature adaptability. Nano Energy, 2019, 61: 617-625

$18 \mathrm{Li} \mathrm{J}, \mathrm{McC}$ Coll K, Lu X, et al. Multi-scale investigations of $\delta-\mathrm{Ni}_{0.25} \mathrm{~V}_{2} \mathrm{O}_{5}$. $n \mathrm{H}_{2} \mathrm{O}$ cathode materials in aqueous zinc-ion batteries. Adv Energy Mater, 2020, 10: 2000058

19 Cao Z, Chu H, Zhang H, et al. An in situ electrochemical oxidation 
strategy for formation of nanogrid-shaped $\mathrm{V}_{3} \mathrm{O}_{7} \cdot \mathrm{H}_{2} \mathrm{O}$ with enhanced zinc storage properties. J Mater Chem A, 2019, 7: 25262-25267

20 Luo $\mathrm{H}$, Wang $\mathrm{B}$, Wang $\mathrm{F}$, et al. Anodic oxidation strategy toward structure-optimized $\mathrm{V}_{2} \mathrm{O}_{3}$ cathode via electrolyte regulation for $\mathrm{Zn}$-ion storage. ACS Nano, 2020, 14: 7328-7337

21 Luo $\mathrm{H}$, Wang B, Wu F, et al. Synergistic nanostructure and heterointerface design propelled ultra-efficient in-situ self-transformation of zinc-ion battery cathodes with favorable kinetics. Nano Energy, 2021, 81: 105601

22 Wang L, Huang KW, Chen J, et al. Ultralong cycle stability of aqueous zinc-ion batteries with zinc vanadium oxide cathodes. Sci Adv, 2019, 5: eaax4279

23 Tang B, Fang G, Zhou J, et al. Potassium vanadates with stable structure and fast ion diffusion channel as cathode for rechargeable aqueous zinc-ion batteries. Nano Energy, 2018, 51: 579-587

24 Song M, Tan H, Chao D, et al. Recent advances in Zn-ion batteries. Adv Funct Mater, 2018, 28: 1802564

25 Oka Y, Yao T, Yamamoto N, et al. Synthesis and crystal structure of $\mathrm{SrV}_{4} \mathrm{O}_{9}$ in a metastable state. J Solid State Chem, 2000, 149: 414-418

26 Liu X, Zhang Y, Zheng J, et al. Facile hydrothermal synthesis and electrochemical properties of $\left(\mathrm{NH}_{4}\right)_{2} \mathrm{~V}_{4} \mathrm{O}_{9}$ sheets for supercapacitor electrode with excellent performance. Mater Lett, 2018, 229: 26-30

27 Kundu D, Adams BD, Duffort V, et al. A high-capacity and long-life aqueous rechargeable zinc battery using a metal oxide intercalation cathode. Nat Energy, 2016, 1: 16119

28 Zhang N, Cheng F, Liu Y, et al. Cation-deficient spinel $\mathrm{ZnMn}_{2} \mathrm{O}_{4}$ cathode in $\mathrm{Zn}\left(\mathrm{CF}_{3} \mathrm{SO}_{3}\right)_{2}$ electrolyte for rechargeable aqueous $\mathrm{Zn}$-ion battery. J Am Chem Soc, 2016, 138: 12894-12901

$29 \mathrm{Hu} \mathrm{L}, \mathrm{Wu} \mathrm{Z}, \mathrm{Lu} \mathrm{C}$, et al. Principles of interlayer-spacing regulation of layered vanadium phosphates for superior zinc-ion batteries. Energy Environ Sci, 2021, 14: 4095-4106

30 Alfaruqi $\mathrm{MH}$, Mathew V, Song J, et al. Electrochemical zinc intercalation in lithium vanadium oxide: A high-capacity zinc-ion battery cathode. Chem Mater, 2017, 29: 1684-1694

$31 \mathrm{Hu} \mathrm{P}$, Zhu $\mathrm{T}$, Wang $\mathrm{X}$, et al. Highly durable $\mathrm{Na}_{2} \mathrm{~V}_{6} \mathrm{O}_{16} \cdot 1.63 \mathrm{H}_{2} \mathrm{O}$ nanowire cathode for aqueous zinc-ion battery. Nano Lett, 2018, 18: 1758-1763

32 He P, Yan M, Zhang G, et al. Layered VS 2 nanosheet-based aqueous $\mathrm{Zn}$ ion battery cathode. Adv Energy Mater, 2017, 7: 1601920

33 He P, Zhang G, Liao X, et al. Sodium ion stabilized vanadium oxide nanowire cathode for high-performance zinc-ion batteries. Adv Energy Mater, 2018, 8: 1702463

$34 \mathrm{Wu}$ B, Zhang G, Yan $\mathrm{M}$, et al. Graphene scroll-coated $\alpha-\mathrm{MnO}_{2}$ nanowires as high-performance cathode materials for aqueous $\mathrm{Zn}$-ion battery. Small, 2018, 14: 1703850

35 Sambandam B, Soundharrajan V, Kim S, et al. Aqueous rechargeable $\mathrm{Zn}$-ion batteries: An imperishable and high-energy $\mathrm{Zn}_{2} \mathrm{~V}_{2} \mathrm{O}_{7}$ nanowire cathode through intercalation regulation. J Mater Chem A, 2018, 6: 3850-3856

36 Xia C, Guo J, Lei Y, et al. Rechargeable aqueous zinc-ion battery based on porous framework zinc pyrovanadate intercalation cathode. Adv Mater, 2018, 30: 1705580

37 Chen $\mathrm{X}$, Wang $\mathrm{L}$, Li H, et al. Porous $\mathrm{V}_{2} \mathrm{O}_{5}$ nanofibers as cathode materials for rechargeable aqueous zinc-ion batteries. J Energy Chem, 2019, 38: 20-25

38 Li G, Yang Z, Jiang Y, et al. Towards polyvalent ion batteries: A zincion battery based on NASICON structured $\mathrm{Na}_{3} \mathrm{~V}_{2}\left(\mathrm{PO}_{4}\right)_{3}$. Nano Energy, 2016, 25: 211-217

39 Kundu D, Hosseini Vajargah S, Wan L, et al. Aqueous vs. nonaqueous Zn-ion batteries: Consequences of the desolvation penalty at the interface. Energy Environ Sci, 2018, 11: 881-892

40 Liu Z, Yang Q, Wang D, et al. A flexible solid-state aqueous zinc hybrid battery with flat and high-voltage discharge plateau. Adv Energy Mater, 2019, 9: 1902473

41 Liu W, Dong L, Jiang B, et al. Layered vanadium oxides with proton and zinc ion insertion for zinc ion batteries. Electrochim Acta, 2019, 320: 134565

42 Oberholzer P, Tervoort E, Bouzid A, et al. Oxide versus nonoxide cathode materials for aqueous $\mathrm{Zn}$ batteries: An insight into the charge storage mechanism and consequences thereof. ACS Appl Mater Interfaces, 2019, 11: 674-682

43 Yang $\mathrm{Y}$, Tang $\mathrm{Y}$, Fang $\mathrm{G}$, et al. $\mathrm{Li}^{+}$intercalated $\mathrm{V}_{2} \mathrm{O}_{5} \cdot n \mathrm{H}_{2} \mathrm{O}$ with enlarged layer spacing and fast ion diffusion as an aqueous zinc-ion battery cathode. Energy Environ Sci, 2018, 11: 3157-3162

44 Zhang N, Jia M, Dong Y, et al. Hydrated layered vanadium oxide as a highly reversible cathode for rechargeable aqueous zinc batteries. Adv Funct Mater, 2019, 29: 1807331

45 Ming F, Liang $\mathrm{H}$, Lei $\mathrm{Y}$, et al. Layered $\mathrm{Mg}_{x} \mathrm{~V}_{2} \mathrm{O}_{5} \cdot n \mathrm{H}_{2} \mathrm{O}$ as cathode material for high-performance aqueous zinc ion batteries. ACS Energy Lett, 2018, 3: 2602-2609

46 Liu Y, $\mathrm{Hu} \mathrm{P}$, Liu $\mathrm{H}$, et al. Tetragonal $\mathrm{VO}_{2}$ hollow nanospheres as robust cathode material for aqueous zinc ion batteries. Mater Today Energy, 2020, 17: 100431

47 Liu C, Neale Z, Zheng J, et al. Expanded hydrated vanadate for highperformance aqueous zinc-ion batteries. Energy Environ Sci, 2019, 12: 2273-2285

48 Baddour-Hadjean R, Raekelboom E, Pereira-Ramos JP. New structural characterization of the $\mathrm{Li}_{x} \mathrm{~V}_{2} \mathrm{O}_{5}$ system provided by Raman spectroscopy. Chem Mater, 2006, 18: 3548-3556

49 Baddour-Hadjean R, Navone C, Pereira-Ramos JP. In situ Raman microspectrometry investigation of electrochemical lithium intercalation into sputtered crystalline $\mathrm{V}_{2} \mathrm{O}_{5}$ thin films. Electrochim Acta, 2009, 54: 6674-6679

50 Baddour-Hadjean R, Pereira-Ramos JP, Navone C, et al. Raman microspectrometry study of electrochemical lithium intercalation into sputtered crystalline $\mathrm{V}_{2} \mathrm{O}_{5}$ thin films. Chem Mater, 2008, 20: 1916-1923

51 Horrocks GA, Likely MF, Velazquez JM, et al. Finite size effects on the structural progression induced by lithiation of $\mathrm{V}_{2} \mathrm{O}_{5}$ : A combined diffraction and Raman spectroscopy study. J Mater Chem A, 2013, 1: $15265-15277$

52 Sanchez C, Livage J, Lucazeau G. Infrared and Raman study of amorphous $\mathrm{V}_{2} \mathrm{O}_{5}$. J Raman Spectrosc, 1982, 12: 68-72

53 Burdyukh SV, Berezina OY, Pergament AL, et al. Effect of hydrogenation on the optical properties and internal electrochromism in vanadium pentoxide xerogel films. Thin Solid Films, 2018, 656: 22-29

$54 \mathrm{Wu} \mathrm{T}$, Zhu K, Qin C, et al. Unraveling the role of structural water in bilayer $\mathrm{V}_{2} \mathrm{O}_{5}$ during $\mathrm{Zn}^{2+}$-intercalation: Insights from DFT calculations. J Mater Chem A, 2019, 7: 5612-5620

Acknowledgements This work was supported by the Engineering and Physical Sciences Research Council (EPSRC, EP/V027433/1) of UK, the National Key Research and Development Program of China (2018YFA0704502 and 2017YFA0700103), the National Natural Science Foundation of China (21703248), the Strategic Priority Research Program of the Chinese Academy of Sciences (XDB20000000), and the Royal Society (RGS\R1\211080, IES\R2\212115) of UK.

Funding note Open Access funding provided thanks to the UK Read and Publish (Springer Compact) agreement.

Author contributions $\mathrm{Li} \mathrm{J}$ and $\mathrm{He} \mathrm{G}$ designed the project; $\mathrm{Li}$ J synthesised the materials, carried out the characterisation and wrote the original draft; Hong $\mathrm{N}$ fabricated the batteries and performed the electrochemical evaluation and helped draft the original manuscript; Luo N performed DFT calculations, Dong $\mathrm{H}$ and Kang $\mathrm{L}$ contributed to TEM and ex-situ characterisations; Peng Z and Jia G helped with electrochemical data analysis. He G directed the project; Chai G, Wang M and He G supervised the project and acquired the funding. All authors contributed to the general discussion and manuscript revision.

Conflict of interest The authors declare that they have no conflict of interest.

Supplementary information Experimental details and supporting data are available in the online version of the paper. 
Open Access This article is licensed under a Creative Commons Attribution 4.0 International License, which permits use, sharing, adaptation, distribution and reproduction in any medium or format, as long as you give appropriate credit to the original author(s) and the source, provide a link to the Creative Commons licence, and indicate if changes were made.

The images or other third party material in this article are included in the article's Creative Commons licence, unless indicated otherwise in a credit line to the material. If material is not included in the article's Creative Commons licence and your intended use is not permitted by statutory regulation or exceeds the permitted use, you will need to obtain permission directly from the copyright holder.

To view a copy of this licence, visit http://creativecommons.org/licenses/ by/4.0/.

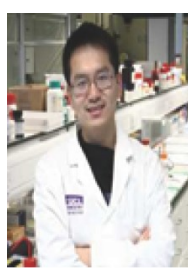

Guanjie $\mathrm{He}$ is an associate professor in materials chemistry, leader for the Advanced Functional Materials Research Group, University of Lincoln and an Honorary Lecturer at University College London (UCL). He received his $\mathrm{PhD}$ degree in 2018 from the Department of Chemistry, UCL. His research focuses on materials for electrochemical energy storage and conversion applications, especially electrode materials in aqueous electrolyte systems.

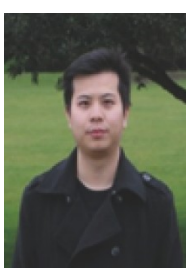

Guoliang Chai has been a Professor at Fujian Institute of Research on the Structure of Matter (FJIRSM), Chinese Academy of Sciences (CAS) since 2016. He received his $\mathrm{PhD}$ degree in 2012 from FJIRSM, CAS. After that, he worked as a postdoc at Tokyo Institute of Technology from 2012 to 2014, and UCL as a research associate from 2014 to 2016. His current research interests focus on electrochemical catalysis, energy storage materials, and first-principles simulations.

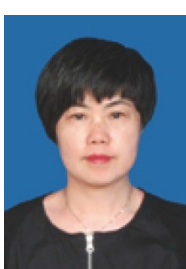

Min Wang is a professor at Qinghai Institute of Salt Lakes, CAS. She is a member of expert panel for the Ministry of Science and Technology of China, National Torch Program, Lithium Branch of China Non-ferrous Metals Industry Association, China Patent Technology Examination. Her research interest includes comprehensive development and industrialisation of potassium, lithium, boron, magnesium resources in salt lake in terms of thermal energy storage, lithium extraction technologies and formulation of salt lake chemical industrial standards.
Jianwei Li received his BSc degree (2012) in material physics from Sun-yat Sen University and $\mathrm{PhD}$ degree from UCL under co-supervision of Prof. Ivan Parkin and Prof. Claire Carmalt in 2021. His research interest includes inorganic material design and synthesis, structural-functional studies and charge storage mechanism for rechargeable aqueous ion batteries.

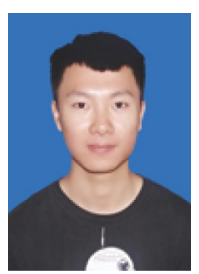

Ningyun Hong received his BSc degree from Henan University in 2017 and MSc degree from Qinghai Institute of Salt Lakes, CAS in 2021. He is currently a PhD candidate at Tianjin University of Technology under the supervision of Prof. Yicheng Wu. His present research interest focuses on the design and synthesis of advanced cathode materials for sodium ion batteries.

\section{原位电化学改性的预插层钒青铜水系锌离子电池正 极材料}

李建伟 ${ }^{1,2 \dagger}$, 洪宁云 ${ }^{2 \dagger}$, 罗宁静 ${ }^{1}$, 东淏博 ${ }^{4}$, 立立群 ${ }^{5}$, 彭正军 ${ }^{2}$, 贾国风 ${ }^{2}$, 柴国良 ${ }^{1^{*}}$, 王敏 ${ }^{*}$, 何冠杰 $3,4,5^{*}$

摘要 钒青铜是一种极具潜力的水系锌离子电池正极材料. 然而, 传统 的单离子预插层 $\mathrm{V}_{2} \mathrm{O}_{5}$ 材料由于自身结构的限制和储锌过程中发生不可 逆的相变使其储锌能力接近上限. 本文采用原位阴极氧化法将准层状 材料 $\mathrm{CaV}_{4} \mathrm{O}_{9}$ 在特定的电解液中将双离子 $\left(\mathrm{Ca}^{2+}, \mathrm{Zn}^{2+}\right)$ 引入 $\delta-\mathrm{V}_{2} \mathrm{O}_{5}$ 晶体 骨架中, 形成超薄钒青铜材料 $\mathrm{Ca}_{0.12} \mathrm{Zn}_{0.12} \mathrm{~V}_{2} \mathrm{O}_{5} \cdot n \mathrm{H}_{2} \mathrm{O}$. 该材料表现出超 高的能量密度 $\left(366 \mathrm{~W} \mathrm{~h} \mathrm{~kg}^{-1}\right.$ ) 和功率密度 $\left(6627 \mathrm{~W} \mathrm{~kg}^{-1}\right)$, 并在大电流 $10 \mathrm{~A} \mathrm{~g}^{-1}$ 下循环 3000 圈后可逆比容量仍高达 $205 \mathrm{~mA} \mathrm{~h} \mathrm{~g}^{-1}$. 通过多种原 位/非原位表征, 系统地揭示了材料与 $\mathrm{Ca}^{2+}$ 电解液添加剂的协同作用, 使结构、电化学可逆性和反应动力学得到有效提升, 并凸显了电解液 调控对转化反应过程的重要性. 经过理论计算, 阐明了双离子预嵌入衍 生的“支柱”增强效应、电荷屏蔽效应和调控电子结构对增强电荷储存 性能的作用. 